\title{
Geochemical characterization of surficial sediments from the southwestern Iberian continental shelf
}

\section{Caracterización geoquímica de los sedimentos superficiales del sudoeste de la plataforma continental ibérica}

\author{
A. Machado ${ }^{1,3}$ \\ F. Rocha ${ }^{1 *}$ \\ M.F. Araújo ${ }^{2}$ \\ F. Vitali ${ }^{2}$ \\ C. Gomes ${ }^{1}$ \\ J.A. Dias $^{3}$ \\ ${ }^{1}$ Centro de Minerais Industrias e Argilas \\ Universidade do Aveiro \\ 3810 Aveiro, Portugal \\ *E-mail: frocha@geo.ua.pt \\ ${ }^{2}$ Instituto Tecnológico e Nuclear \\ Química, E.N. 10 \\ 2686-953 Sacavém, Portugal \\ ${ }^{3}$ CIACOMAR \\ Universidade do Algarve \\ Campus de Gambelas \\ 8000 Faro. Portugal
}

Recibido en junio de 2003; aceptado en abril de 2004

\begin{abstract}
The impact of trace elements (Ba, Nb, Zr, Y, Sr, Rb, Pb, As, Zn, Cu, Ni, Co, Cr, V, La, Ce, Nd, Sm, Eu, Tb, Yb and Lu) transported by the Guadiana, Tinto-Odiel and Guadalquivir rivers on sediments from the southwestern Iberian continental shelf has been studied. Shelf surficial sediments from three transects established right in front of the river estuaries were characterized by specific signatures relative to those trace elements. The Guadiana transect shows high Zr concentration values; the Tinto-Odiel transect shows high heavy metal ( $\mathrm{Pb}, \mathrm{As}, \mathrm{Zn}$ and $\mathrm{Cu}$ ) concentration values; and the Guadalquivir transect shows high $\mathrm{Sr}$ concentration values. Data from the statistical analysis indicate three distinct sources for trace elements: lithogenic, biogenic and anthropogenic.
\end{abstract}

Key words: trace elements, rare earth elements, fine sediments, continental shelf, Iberian Peninsula.

\section{Resumen}

Se estudió el impacto de los elementos traza (Ba, Nb, Zr, Y, Sr, Rb, Pb, As, Zn, Cu, Ni, Co, Cr, V, La, Ce, Nd, Sm, Eu, Tb, Yb y Lu) acarreados por los ríos Guadiana, Tinto-Odiel y Guadalquivir sobre los sedimentos del sudoeste de la plataforma continental ibérica. Los sedimentos superficiales de tres transectos establecidos enfrente de los estuarios de los ríos se caracterizaron por las huellas específicas en lo que involucra a aquellos elementos. El transecto de Guadiana muestra valores altos de concentración de Zr; el transecto de Tinto-Odiel muestra valores altos de concentración para los metales pesados (Pb, As, Zn y Cu); y el transecto de Guadalquivir muestra valores altos de concentración de Sr. Los datos del análisis estadístico señalan tres fuentes distintas para los elementos traza: litogénica, biogénica y antropogénica.

Palabras clave: elementos traza, tierras raras (REE), sedimentos finos, plataforma continental, Península Ibérica. 


\section{Introduction}

Chemical composition of shelf sediments is highly dependent on factors such as climate, vegetation cover, geomorphology, pedogenetic processes and soil nature, as well as river hydrodynamics, chemical activity and anthropogenic activity.

During the last decade, several studies have been conducted on the mineralogical composition of sea-bottom sediments, of particulate materials in suspension and on cores, which together with paleontological and geochemical data are used for paleoclimatic and paleoenvironmental reconstructions, analysis of sea-level changes, identification of stratigraphic correlations, past and present sources of the sediments and means of terrigenous supply, dispersion of pollution and, finally, to describe the present oceanic water masses (Drago et al., 2002; Machado et al., 1999a, 1999b, 2000a, 2000b, 2001a, 2001b, 2002; Martins et al., 2001a, 2001b, 2002; Oliveira et al., 1998, 2000, 2001, 2002; Vidinha et al., 1998, 2000, 2002).

The study area of the present work is located between Vila Real de Santo António (Portugal) and Cadiz (Spain), more precisely in the continental shelf off the Guadiana, Piedras, Tinto-Odiel and Guadalquivir estuaries, limited by the coastline and the 200-m bathymetric curve.

The low density geochemical survey of Portugal put in evidence (Ferreira, 2000) some geochemical patterns, related to features such as geological aspects (lithology, occurrence of particular mineralization, structural zones, metallogenic provinces), surficial environment conditions and anthropogenic influences (mining activities, agriculture, industrialized areas). Recent studies have shown that the Iberian Pyrite Belt is the main source of $\mathrm{Ni}, \mathrm{Cu}, \mathrm{Cd}, \mathrm{Zn}$ and As found in sediments of the western Mediterranean basin (Elbaz-Poulichet et al., 2001). On the southwestern coast of Spain, some of the processes referred to act cooperatively in the Tinto-Odiel fluvial system, one of the most polluted areas of the world primarily due to the mining activities that have taken place for many years in the Pyrite Belt (Pérez et al., 1991; Cabrera et al., 1992; Nelson and Lamothe, 1993).

The part of the continental shelf studied receives considerable fluvial input from the Guadiana, Tinto-Odiel and Guadalquivir rivers, and to a lesser extent from the Gilão and Piedras rivers, all of them draining the Iberian Pyrite Belt.

The main goal of the present study is to investigate the distribution patterns of the trace elements analyzed, including the rare earth elements (REE), on the continental shelf sediments, in particular in their silt and clay fractions, using geochemical criteria recommended by Chamley (1989). Sediment sampling took place along three transects off the Guadiana, Tinto-Odiel and Guadalquivir estuaries and the geochemical anomalies displayed by the sediments analyzed were determined.

\section{Materials and methods}

The sector of the continental shelf under study is located in the southwestern Iberian Peninsula, between the mouths of the

\section{Introducción}

La composición química de los sedimentos de la plataforma continental está muy ligada a factores como el clima, la cobertura vegetal, la geomorfología, los procesos pedogenéticos y la naturaleza del suelo, así como a la hidrodinámica de ríos, la actividad química y la activiad antropogénica.

En la última década se han llevado a cabo varios estudios sobre la composición mineralógica de los sedimentos del fondo marino, de materiales particulados suspendidos y en núcleos, que junto con datos paleontológicos y geoquímicos se utilizan para hacer reconstrucciones paleoclimáticas y paleoambientales, analizar cambios en el nivel del mar, identificar correlaciones estratigráficas y de fuentes anteriores y actuales de sedimentos y vías de aportación terrígena, así como para describir las masas oceánicas actuales (Drago et al., 2002; Machado et al., 1999a, 1999b, 2000a, 2000b, 2001a, 2001b, 2002; Martins et al., 2001a, 2001b, 2002; Oliveira et al., 1998, 2000, 2001, 2002; Vidinha et al., 1998, 2000, 2002).

El área de estudio del presente trabajo se localiza entre Vila Real de Santo Antonio (Portugal) y Cádiz (España), sobre la plataforma continental enfrente de los estuarios de Guadiana, Piedras, Tinto-Odiel y Guadalquivir, limitada por la línea de costa y la curva batimétrica de $200 \mathrm{~m}$.

El estudio geoquímico de baja densidad de Portugal evidenció (Ferreira, 2000) algunos patrones geoquímicos relacionados con aspectos geológicos (litología, ocurrencia de mineralización particular, zonas estructurales, provincias metalogénicas), condiciones ambientales superficiales e influencias antropogénicas (actividades de minería, agricultura, áreas industriales). Estudios recientes han mostrado que el Cinturón Pirítico Ibérico es la fuente principal de $\mathrm{Ni}, \mathrm{Cu}, \mathrm{Cd}$, Zn y As para los sedimentos de la cuenca Mediterránea occidental (Elbaz-Poulichet et al., 2001). En la costa sudoccidental de España algunos de los procesos mencionados actúan de manera conjunta en el sistema fluvial de Tinto-Odiel, una de las áreas más contaminadas en el mundo principalmente debido a las actividades mineras que se han realizado durante muchos años en el Cinturón Pirítico (Pérez et al., 1991; Cabrera et al., 1992; Nelson y Lamothe, 1993).

La zona de la plataforma continental estudiada recibe aportes fluviales considerables de los ríos Guadiana, Tinto-Odiel y Guadalquivir, y en menor grado de los ríos Gilão y Piedras, todos de ellos drenando el Cinturón Pirítico Ibérico.

El objetivo principal de este estudio fue investigar los patrones de distribución de los metales traza analizados, incluyendo los elementos del grupo de las tierras raras (REE, por sus siglas en inglés), en los sedimentos de la plataforma continental, en particular en sus fracciones de limo y arcilla, utilizando los criterios geoquímicos recomendados por Chamley (1989). El muestreo de los sedimentos se realizó a lo largo de tres transectos ubicados frente a los estuarios de Guadiana, Tinto-Odiel y Guadalquivir, y se determinaron las anomalías geoquímicas de los sedimentos analizados. 
Guadiana and Guadalquivir rivers, and limited by the coastline and the 200-m bathymetric line. Sediment sampling was carried out in February 2001 (rainy period), on board the research vessel N.R.P. Andrómeda from the Portuguese Hydrographic Institute, using a Smith-McIntyre sampler, with a PVC core. For the present study, 20 samples were selected from the total collected at the transects referred to (fig. 1), 8 off the Guadiana estuary, 5 off the Tinto-Odiel estuary and 7 off the Guadalquivir estuary.

After rinsing with distilled water, samples were wet sieved through a 400 ASTM sieve (0.038-mm mesh). Sediment fractions $<0.038 \mathrm{~mm}$ were dried in an oven at $60^{\circ} \mathrm{C}$ and gently disaggregated with a porcelain mortar.

The fine fractions $(<38 \mu \mathrm{m})$ of the surficial sediments were analyzed using the X-ray fluorescence spectrometer (Philips, model PW 1400) of the Department of Geosciences laboratory at Aveiro University. Fourteen trace elements (Ba, Nb, Zr, Y, $\mathrm{Sr}, \mathrm{Rb}, \mathrm{Pb}, \mathrm{As}, \mathrm{Zn}, \mathrm{Cu}, \mathrm{Ni}, \mathrm{Co}, \mathrm{Cr}$ and $\mathrm{V}$ ) were determined. Eight REE (La, Ce, Nd, Sm, Eu, Tb, Yb and Lu) were also determined, with an accuracy better than 5\% (Gouveia and Prudêncio, 2000), by neutron activation analysis using the nuclear reactor operating at the laboratory of the Instituto Tecnológico e Nuclear, in Sacavém (Portugal).

The data obtained were statistically treated by principal components analysis, using Statistica 5.0 software from StatSoft, and the parameters selected were mapped using Surfer 7.0 software from Golden Software.

\section{Results}

Table 1 shows the main previously analyzed (Machado et al., 2000a, 2000b, 2001a, 2001b) characteristics of the samples studied (concerning depth, lithology and mineralogy). The sediments consist mostly of fine- to medium-grain sand, sandy mud and mud, sometimes containing shell fragments.

According to Machado et al. (2000a), the fine fraction ( $<38 \mathrm{~mm}$ ) presents a variable quantitative mineralogical composition: quartz $(\mathrm{Qz})$ is the dominant mineral, phyllosilicates

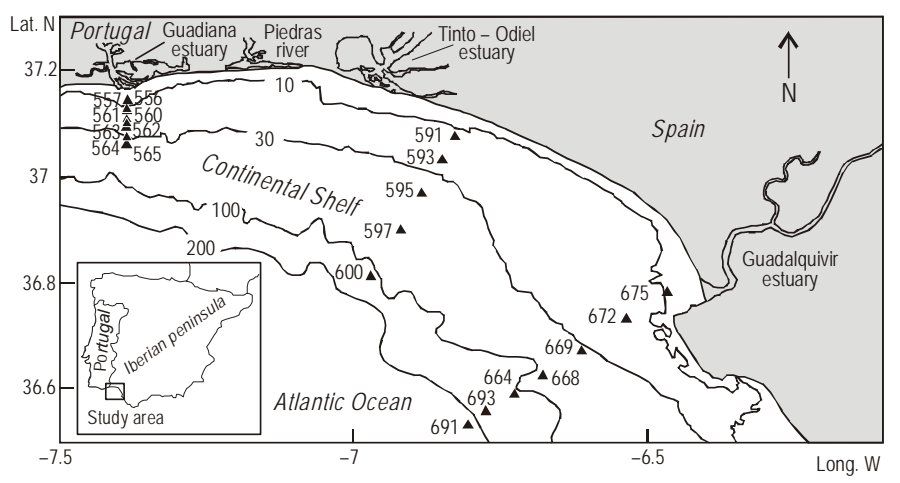

Figure 1. Sampling map (20 grab samples from three transects: Guadiana, Tinto-Odiel and Guadalquivir).

Figura 1. Mapa de muestreo (20 muestras de draga de tres transectos: Guadiana, Tinto-Odiel y Guadalquivir).

\section{Materiales y métodos}

La parte de la plataforma continental bajo estudio se localiza en el sudoeste de la península ibérica, entre las bocas de los ríos Guadiana y Guadalquivir, limitada por la línea de costa y la línea batimétrica de $200 \mathrm{~m}$. El muestreo de los sedimentos se llevó a cabo en febrero de 2001 (época de lluvias), a bordo del barco oceanográfico N.R.P. Andrómeda del Instituto Hidrográfico de Portugal, utilizando una draga tipo SmithMcIntyre, con un núcleo de PVC. Para el present estudio, se seleccionaron 20 muestras del total recolectado en los tres transectos establecidos (fig. 1), 8 frente al estuario del Guadiana, 5 frente al del Tinto-Odiel y 7 frente al del Guadalquivir.

Después de lavar con agua destilada, las muestras se tamizaron en húmedo a través de una malla ASTM 400 $(0.038 \mathrm{~mm})$. Las fracciones de sedimento $<0.038 \mathrm{~mm}$ fueron secadas a $60^{\circ} \mathrm{C}$ en un horno y suavemente separadas con un mortero de porcelana.

Las fracciones finas $(<38 \mu \mathrm{m})$ de los sedimentos superficiales fueron analizadas con un espectrómetro de fluorescencia de rayos X (Philips, modelo PW 1400) del laboratorio del Departamento de Geociencias de la Universidad de Aveiro. Se determinaron 14 elementos traza (Ba, Nb, Zr, Y, Sr, Rb, Pb, As, $\mathrm{Zn}, \mathrm{Cu}, \mathrm{Ni}, \mathrm{Co}, \mathrm{Cr}$ y V). También se determinaron 8 REE (La, $\mathrm{Ce}, \mathrm{Nd}, \mathrm{Sm}, \mathrm{Eu}, \mathrm{Tb}, \mathrm{Yb}$ y Lu) con una precisión mayor que $5 \%$ (Gouveia y Prudêncio, 2000), utilizando análisis por activación mediante bombardeo neutrónico con el reactor nuclear del laboratorio del Instituto Tecnológico e Nuclear en Sacavém (Portugal).

Los datos obtenidos fueron tratados estadísticamente mediante un análisis de componentes principales, utilizando la paquetería Statistica 5.0 de StatSoft, y los parámetros seleccionados fueron graficados utilizando la paquetería Surfer 7.0 de Golden Software.

\section{Resultados}

En la tabla 1 se muestran las principales características analizadas previamente (Machado et al., 2000a, 2000b, 2001a, 2001b) de las muestras estudiadas (en cuanto a profundidad, litología y mineralogía). Los sedimentos se componen principalmente de arena de grano fino a medio, limo arenoso y limo, conteniendo a veces fragmentos de concha.

De acuerdo con Machado et al. (2000a), la fracción fina (<38 mm) presenta una composición mineralógica cuantitativa variable: el cuarzo (Qz) es el mineral dominante; los filosilicatos (Phyl), principalmente mica/ilita, el feldespato-K (FK), la plagioclasa (Plag), la dolomita (Dol), la anhidrita y la calcita (Cal) son los minerales principales, mientras que ópalo C/CT, anatasa, siderita y pirita son minerales accesorios.

En cuanto a la composición mineralógica de la fracción $<2 \mu \mathrm{m}$ (fig. 2), la ilita (I) es el mineral dominante, junto con la caolinita (K) y la esmectita (Sm). También se encuentran 
Table 1. Main lithological and mineralogical characteristics of the samples studied.

Tabla 1. Principales características litológicas y mineralógicas de las muestras estudiadas.

\begin{tabular}{|c|c|c|c|c|c|}
\hline Transect & $\begin{array}{l}\text { Sample } \\
\text { Ref. }\end{array}$ & $\begin{array}{l}\text { Bathymetry } \\
\text { (m) }\end{array}$ & Lithology & $\begin{array}{l}\text { Mineralogy of }<38 \mu \mathrm{m} \text { fraction } \\
\text { (Machado et al., 2000a) }\end{array}$ & $\begin{array}{l}\text { Mineralogy of }<38 \mu \mathrm{m} \text { fraction } \\
\text { (Machado et al., 2001a) }\end{array}$ \\
\hline \multirow[t]{8}{*}{ Guadiana } & 556 & 7 & Muddy sand & Phyl $>$ Qz $>$ Plag $>$ Cal $>$ FK $\approx$ Dol & $\mathrm{I}>>\mathrm{K}>\mathrm{Sm}>\mathrm{Cl} \approx \mathrm{I}-\mathrm{Sm}$ \\
\hline & 557 & 11 & Mud & & \\
\hline & 560 & 12 & Coarse sand & & \\
\hline & 561 & 15 & Gravel sand & & \\
\hline & 562 & 19 & Gravel sand & & \\
\hline & 563 & 22 & Gravel sand & & \\
\hline & 564 & 36 & Mud & & \\
\hline & 565 & 48 & Compact mud & & \\
\hline \multirow[t]{5}{*}{ Tinto-Odiel } & 591 & 18 & Mud & Cal $\approx$ Phyl $>$ Qz $>$ Dol $>$ Plag $>$ FK & $\mathrm{I}>>\mathrm{K}>\mathrm{Sm}>\mathrm{I}-\mathrm{Sm} \approx \mathrm{Cl}$ \\
\hline & 593 & 25 & Mud & & \\
\hline & 595 & 42 & Compact mud & & \\
\hline & 597 & 66 & Compact mud & & \\
\hline & 600 & 108 & Mud & & \\
\hline \multirow[t]{7}{*}{ Guadalquivir } & 675 & 10 & Compact mud & Cal $>$ Phyl $>$ Qz $>$ Dol $>$ Plag $>$ FK & $\mathrm{I}>\mathrm{K}>\mathrm{Sm}>\mathrm{I}-\mathrm{Sm}>\mathrm{Cl}$ \\
\hline & 672 & 18 & Compact mud & & \\
\hline & 669 & 37 & Compact mud & & \\
\hline & 666 & 71 & Compact mud & & \\
\hline & 664 & 97 & Compact mud & & \\
\hline & 693 & 143 & Sandy mud & & \\
\hline & 691 & 251 & Sandy mud & & \\
\hline
\end{tabular}

(Phyl), mostly mica/illite, K-feldspar (FK), plagioclase (Plag), dolomite (Dol), anhydrite and calcite (Cal) are the main minerals, while opal C/CT, anatase, siderite and pyrite are the accessory minerals identified.

Regarding the mineralogical composition of the $<2 \mu \mathrm{m}$ fraction (fig. 2), illite (I) is the predominant mineral, accompanied by kaolinite $(\mathrm{K})$ and smectite $(\mathrm{Sm})$. Chlorite $(\mathrm{Cl})$ and illite-smectite (I-Sm) are also present, generally in very discreet amounts (Machado et al., 2001a, 2001b).

Table 2 presents all the geochemical data $(\mathrm{Ba}, \mathrm{Nb}, \mathrm{Zr}$, Y, Sr, Rb, Pb, As, Zn, Cu, Ni, Co, Cr, V, La, Ce, Nd, Sm, Eu, Tb, Yb and $\mathrm{Lu}$ ) obtained for the three transects studied (Guadiana, Tinto-Odiel and Guadalquivir).

Table 3 shows both the minimum and maximum contents for each element analyzed in the three transects. As the main goal of this research was the identification of eventual geochemical anomalies found in the sediments, we also exhibit the values of the elementary composition of average shale (Turekian and Wedepohl, 1961; Mason and Moore, 1982), in regard to the trace elements analyzed. clorita (Cl) e ilita-esmectita (I-Sm), generalmente en cantidades pequeñas (Machado et al., 2001a, 2001b).

En la tabla 2 se presentan todos los datos geoquímicos (Ba, $\mathrm{Nb}, \mathrm{Zr}, \mathrm{Y}, \mathrm{Sr}, \mathrm{Rb}, \mathrm{Pb}, \mathrm{As}, \mathrm{Zn}, \mathrm{Cu}, \mathrm{Ni}, \mathrm{Co}, \mathrm{Cr}, \mathrm{V}, \mathrm{La}, \mathrm{Ce}, \mathrm{Nd}$, $\mathrm{Sm}, \mathrm{Eu}, \mathrm{Tb}, \mathrm{Yb}$ y Lu) obtenidos en los tres transectos estudiados (Guadiana, Tinto-Odiel y Guadalquivir).

En la tabla 3 se muestran los contenidos mínimo y máximo para cada elemento analizado en los tres transectos. Siendo el objetivo principal de esta investigación la identificación de anomalías geoquímicas eventuales en los sedimentos, también se muestran los valores de la composición elemental media de la lutita (Turekian y Wedepohl, 1961; Mason y Moore, 1982) en cuanto a los elementos traza analizados.

En términos generales, $\mathrm{Zr}, \mathrm{Sr}, \mathrm{Pb}, \mathrm{As}, \mathrm{Zn}, \mathrm{Cr}$ y $\mathrm{Cu}$ (con concentraciones más altas que las publicadas para lutita en promedio), así como Ba, Y, Rb, Ni, Co y V (con concentraciones más bajas que la lutita en promedio) muestran concentraciones anómalas en los sedimentos superficiales de la sección de la plataforma continental ibérica estudiada. Sólo el Nb muestra concentraciones que concuerdan con los valores normales. 


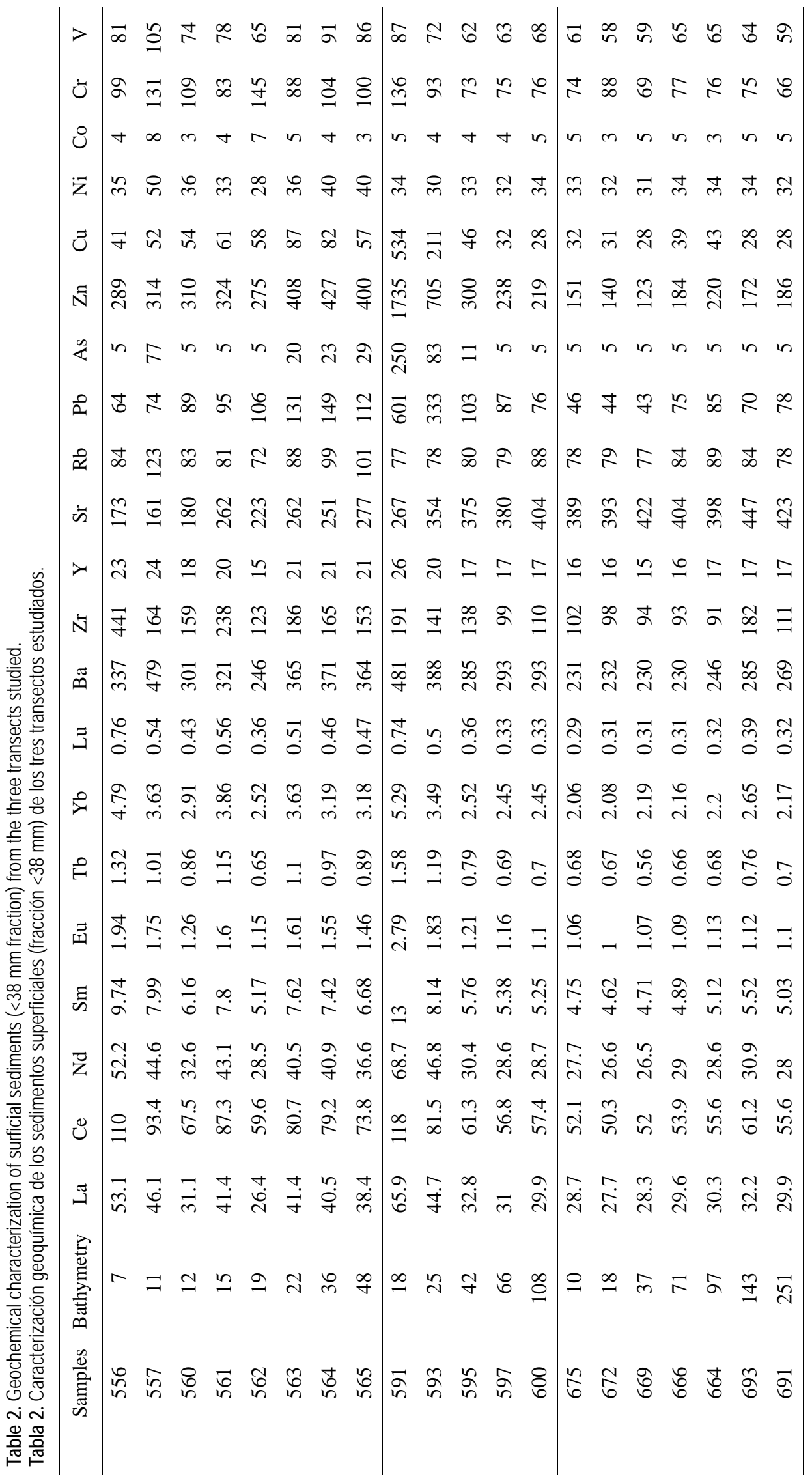



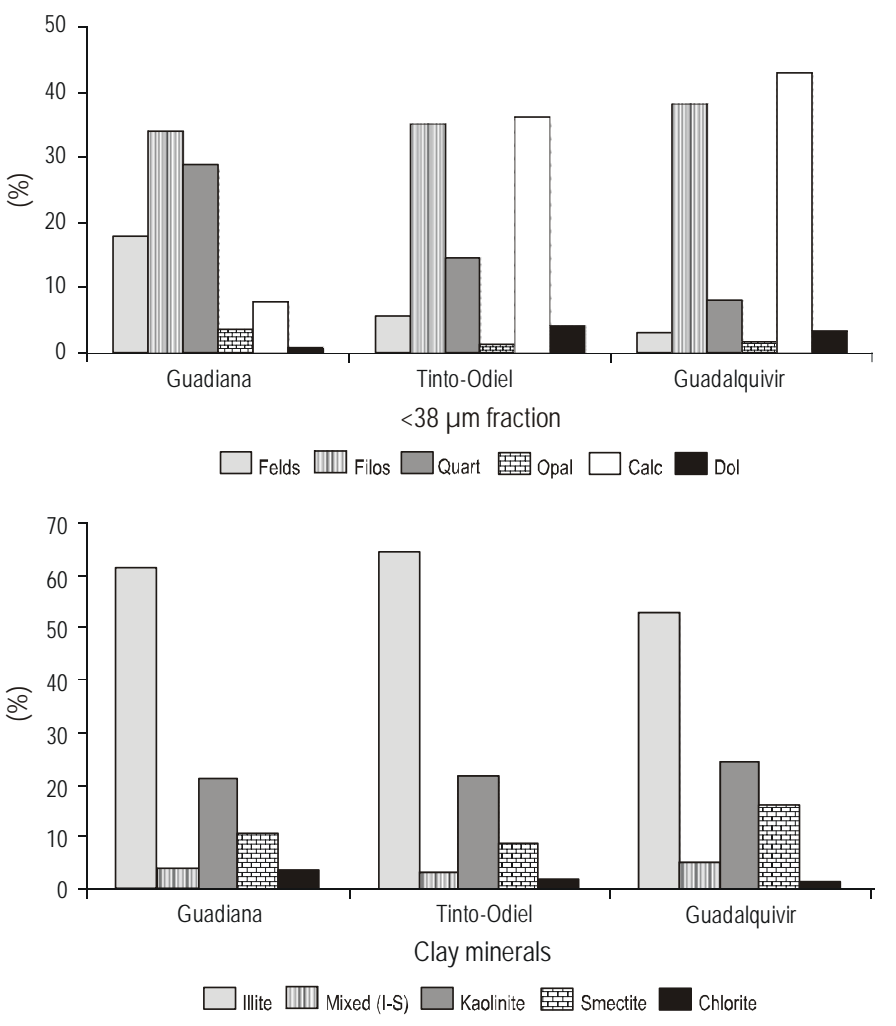

Figure 2. Mineral composition (\%) of both the $<38 \mathrm{~mm}$ and $<2 \mathrm{~mm}$ fractions of the sediments from the transects off the Guadiana, Tinto-Odiel and Guadalquivir estuaries.

Figura 2. Composición de minerales (\%) de las fracciones de $<38 \mathrm{~mm} \mathrm{y}<2$ $\mathrm{mm}$ de los sedimentos de los transectos frente a los estuarios de Guadiana, Tinto-Odiel y Guadalquivir.

In general terms, $\mathrm{Zr}, \mathrm{Sr}, \mathrm{Pb}, \mathrm{As}, \mathrm{Zn}, \mathrm{Cr}$ and $\mathrm{Cu}$ (showing concentrations higher than those published for average shale) and $\mathrm{Ba}, \mathrm{Y}, \mathrm{Rb}, \mathrm{Ni}, \mathrm{Co}$ and $\mathrm{V}$ (showing concentrations lower than the average shale) show anomalous concentrations in the surficial sediments of the section of the Iberian shelf studied. Only Nb shows concentrations in accordance with the normal values. Martin and Meybeck (1979) indicated the increment of concentrations for elements such as $\mathrm{Cu}, \mathrm{Pb}$ and $\mathrm{Zn}$, whereas elements like $\mathrm{Ba}, \mathrm{Y}, \mathrm{Rb}, \mathrm{Ni}$, Co and $\mathrm{V}$ showed concentration values equivalent to the theoretical ones.

Figure 3 shows the distribution of $\mathrm{Sr}, \mathrm{Pb}, \mathrm{Zn}, \mathrm{Cu}$, As and $\mathrm{Zr}$ concentration values, which are very high when compared with those published for average shale. It is interesting to note that the highest $\mathrm{Zr}$ concentration values occur along the transect off the Guadiana estuary, whereas Sr concentrations are higher in the transect off the Guadalquivir estuary. On the other hand, $\mathrm{Ba}, \mathrm{Y}, \mathrm{Rb}, \mathrm{Ni}, \mathrm{Co}$ and $\mathrm{V}$ are present in lower concentrations (fig. 4), compared with those referred to by Turekian and Wedepohl (1961) and Mason and Moore (1982) for average shale. Figure 4 shows that the sediments of the Guadalquivir transect contain very low $\mathrm{Ba}, \mathrm{Y}, \mathrm{Rb}, \mathrm{Ni}$, Co and $\mathrm{V}$ contents, compared to those determined in the other two transects.

Also, when analyzing the REE concentrations in sediments and/or sedimentary rocks, it is common to normalize those
Martin y Meybeck (1979) indicaron un incremento en las concentraciones de elementos como $\mathrm{Cu}, \mathrm{Pb}$ y $\mathrm{Zn}$, mientras que elementos como $\mathrm{Ba}, \mathrm{Y}, \mathrm{Rb}, \mathrm{Ni}$, Co y $\mathrm{V}$ presentaron valores equivalentes a los teóricos.

La figura 3 muestra la distribución de los valores de concentración de $\mathrm{Sr}, \mathrm{Pb}, \mathrm{Zn}, \mathrm{Cu}$, As y Zr, los cuales son muy altos en comparación con los publicados para la lutita media. Es interesante notar que los valores más altos de $\mathrm{Zr}$ se presentan en el transecto de Guadiana, mientras que las concentraciones de $\mathrm{Sr}$ son mayores en el transecto de Guadalquivir. Por otro lado, Ba, Y, Rb, Ni, Co y V tienen concentraciones menores (fig. 4) en comparación con las mencionadas por Turekian y Wedepohl (1961) y Mason y Moore (1982) para la lutita media. En la figura 4 se observa que los sedimentos del transecto de Guadalquivir tienen contenidos muy bajos de Ba, Y, $\mathrm{Rb}, \mathrm{Ni}$, Co y V, en comparación con los obtenidos en los otros dos transectos.

Asimismo, al analizar las concentraciones de REE en sedimentos y/o rocas sedimentarias, es común normalizar sus valores utilizando las concentraciones de REE de un sedimento/roca sedimentaria común, como el compuesto de lutita para América del Norte (NASC, por sus siglas en inglés). En general, los sedimentos superficiales estudiados muestran cuatro concentraciones de REE que son anómalas con respecto a los valores del NASC (tabla 4). En los casos de los transectos de Guadiana y Tinto-Odiel, los sedimentos tienen concentraciones de REE por arriba de los valores medios de base, mientras que las muestras del transecto de Guadalquivir contienen concentraciones por abajo de los valores promedio de base.

\section{Discusión}

\section{Transecto de Guadiana}

En los sedimentos del transecto de Guadiana las concentraciones de $\mathrm{Pb}, \mathrm{Zn}, \mathrm{As}$ y $\mathrm{Cu}$ se incrementan ligeramente a medida que se incrementa la profundidad de la plataforma. Esto puede deberse a la disminución del tamaño de grano del sedimento y a la existencia de materia orgánica, lo que se asocia con la presencia de minerales sulfíticos (procedentes del Cinturón Pirítico Ibérico).

Según Ferreira (2000), se encuentran anomalías positivas de $\mathrm{Pb}$, relacionadas con metasedimentos que afloran en el Cinturón Pirítico Ibérico; de Zn, relacionadas con los metasedimentos que afloran en la zona sur de Portugal y en la zona central de la península ibérica; de As, relacionadas con la zona central de la península ibérica; y de $\mathrm{Cu}$, relacionadas tanto con el Cinturón Pirítico Ibérico como con Zona Sur Portuguesa.

Las concentraciones relativamente altas de $\mathrm{Zr}$ en la desembocadora del Río Guadiana probablemente se deban a la presencia de minerales con $\mathrm{Zr}$, tales como la biotita derivada de la erosión de rocas metamórficas (esquistos, grauvacas y lutitas), las cuales están muy bien representadas en la cuenca hidrográfica del Guadiana. 
Table 3. Concentrations of trace elements (min-max), in $\mathrm{mg} \mathrm{g}^{-1}$, of the sediments studied and the mean composition of average shale.

Tabla 3. Concentraciones de los elementos traza (mín-máx), en $\mathrm{mg} \mathrm{g}^{-1}$, de los sedimentos estudiados y la composición media de la lutita.

\begin{tabular}{|c|c|c|c|c|c|}
\hline Elements & $\begin{array}{c}\text { Transects } \\
\text { (20 samples) }\end{array}$ & $\begin{array}{l}\text { Guadiana } \\
\text { (8 samples) }\end{array}$ & $\begin{array}{l}\text { Tinto-Odiel } \\
\text { (5 samples) }\end{array}$ & $\begin{array}{l}\text { Guadalquivir } \\
\text { (7 samples) }\end{array}$ & Average shale \\
\hline $\mathrm{Ba}$ & $230-481$ & $301-479$ & $285-481$ & $230-285$ & 580 \\
\hline $\mathrm{Nb}$ & 8-16 & $8-16$ & 9-11 & $9-10$ & 11 \\
\hline $\mathrm{Zr}$ & 91-441 & $\underline{123}-\underline{441}$ & 99-191 & 91-182 & 160 \\
\hline $\mathrm{Y}$ & $15-26$ & $15-24$ & $17-26$ & $15-17$ & 26 \\
\hline $\mathrm{Sr}$ & $161-447$ & $161-307$ & 267-404 & $\underline{389}-\underline{447}$ & 300 \\
\hline $\mathrm{Rb}$ & 72-123 & $72-123$ & $77-88$ & 77-89 & 140 \\
\hline $\mathrm{Pb}$ & 43-601 & 64-149 & $\underline{76}-\underline{601}$ & $43-85$ & 20 \\
\hline As & 5-250 & 5-77 & $\underline{11}-\underline{250}$ & 5 & 13 \\
\hline $\mathrm{Zn}$ & 123-1735 & 275-435 & $\underline{219}-\underline{1735}$ & $123-220$ & 95 \\
\hline $\mathrm{Cu}$ & 28-534 & 41-87 & $\underline{28}-\underline{534}$ & $28-43$ & 45 \\
\hline $\mathrm{Ni}$ & $31-50$ & $28-50$ & $30-34$ & $31-34$ & 68 \\
\hline Co & $3-8$ & $3-8$ & $4-5$ & $3-5$ & 19 \\
\hline $\mathrm{Cr}$ & 73-145 & $\underline{83}-\underline{145}$ & 73-136 & $66-88$ & 90 \\
\hline V & 58-105 & 65-105 & $62-87$ & $58-65$ & 130 \\
\hline Org. Mat. & $0.6-4.7$ & $0.6-4.7$ & $2.8-4.5$ & $1.6-4.1$ & - \\
\hline
\end{tabular}

Values above the average in bold, values below the average in italic and values significantly above the average underlined.

values using the REE concentrations exhibited by an "average" sediment/sedimentary rock, such as the North American Shale Composite (NASC). In general, the surface sediments studied show four REE concentrations that are anomalous with regard to NASC values (table 4). In the cases of the Guadiana and Tinto-Odiel transects, the sediments contain REE
Asimismo, en el transecto de Guadiana, las concentraciones de $\mathrm{Ba}, \mathrm{Y}, \mathrm{Rb}, \mathrm{Ni}$, Co y $\mathrm{V}$ decrecen con la distancia a la costa. Este comportamiento particular podría considerarse una huella del Río Guadiana. Por otro lado, las concentraciones más altas de $\mathrm{Nb}$ y $\mathrm{Cr}$ fueron encontradas en los sedimentos del transecto de Guadiana.

Table 4. Contents of rare earth elements (REE), in $\mathrm{mg} \mathrm{g}^{-1}$, for the North American Shale Composite (NASC) (Haskin et al., 1968) and for the sediments of the three transects studied.

Tabla 4. Contenidos de los elementos del grupo de las tierras raras (REE), en $\mathrm{mg} \mathrm{g}^{-1}$, del Compuesto Lutita de América del Norte (NASC, por sus siglas en inglés) y de los sedimentos de los tres transectos estudiados.

\begin{tabular}{ccccc}
\hline Element & $\begin{array}{c}\text { Abundance } \\
\text { Guadiana }\end{array}$ & $\begin{array}{c}\text { Abundance } \\
\text { Tinto-Odiel }\end{array}$ & $\begin{array}{c}\text { Abundance } \\
\text { Guadalquivir }\end{array}$ & $\begin{array}{c}\text { Abundance } \\
\text { NASC }\end{array}$ \\
\hline La & $\mathbf{3 9 . 8}$ & $\mathbf{4 0 . 9}$ & 29.5 & 32 \\
$\mathrm{Ce}$ & $\mathbf{8 1 . 4}$ & $\mathbf{7 5}$ & 54.4 & 73 \\
$\mathrm{Nd}$ & $\mathbf{3 9 . 9}$ & $\mathbf{4 0 . 6}$ & 28.2 & 33 \\
$\mathrm{Sm}$ & $\mathbf{7 . 3}$ & $\mathbf{7 . 5}$ & 4.9 & 5.7 \\
$\mathrm{Eu}$ & $\mathbf{1 . 5 4}$ & $\mathbf{1 . 6 2}$ & 1.11 & 0.24 \\
$\mathrm{~Tb}$ & $\mathbf{0 . 9 9}$ & $\mathbf{0 . 9 9}$ & 0.67 & 3.1 \\
$\mathrm{Yb}$ & $\mathbf{3 . 4}$ & $\mathbf{3 . 2}$ & 2.2 & 0.48 \\
$\mathrm{Lu}$ & $\mathbf{0 . 5 1}$ & 0.45 & 0.32 & 0.24 \\
\hline
\end{tabular}

Values above the average in bold and values below the average in italic. 
concentrations above the average background values, whereas the samples from the Guadalquivir transect contain concentrations below the average background values.

\section{Discussion}

\section{Guadiana transect}

In the Guadiana transect sediments, $\mathrm{Pb}, \mathrm{Zn}$, As and $\mathrm{Cu}$ concentrations slightly increase with increasing shelf depth. This could be related to the decrease of sediment grain size and the existence of organic matter, which is associated with the presence of sulphite minerals (coming from the Iberian Pyrite Belt).

According to Ferreira (2000), positive anomalies are found of: $\mathrm{Pb}$, related to the metasediments outcropping along the Iberian Pyrite Belt; $\mathrm{Zn}$, related to the metasediments outcropping in the Southern Portuguese Zone and in the Central Iberian Zone; As, related to the Central Iberian Zone formations; and $\mathrm{Cu}$, related to both the Iberian Pyrite Belt and the Southern Portuguese Zone.

The relatively high $\mathrm{Zr}$ concentrations found near the outlet of the Guadiana River are most probably due to the presence of Zr-bearing minerals, such as biotite derived from the erosion of the metamorphic rocks (schists, graywackes and shales) that are very well represented in the Guadiana hydrographic basin.

\section{Transecto de Tinto-Odiel}

Frente al estuario de Tinto-Odiel, los sedimentos superficiales de la plataforma continental están fuertemente contaminados por metales pesados tales como $\mathrm{Cu}, \mathrm{Zn}$ y $\mathrm{Pb}$. Esto se asocia con minerales sulfíticos procedentes de fuentes en el Cinturón Pirítico Ibérico y de desechos de minerales de las plantas industriales ubicadas cerca del margen estuarino (Ruiz, 2001).

El estuario de Tinto-Odiel parece jugar un papel importante en la distribución de $\mathrm{Pb}, \mathrm{Zn}$, As y Cu. La concentración de estos elementos se reduce fuertemente en las zonas de la plataforma continental media y exterior. Lo más probable es que las concentraciones relativamente altas de metales pesados en los sedimentos de este transecto estén relacionadas con las actividades mineras en esta cuenca.

\section{Transecto de Guadalquivir}

Las concentraciones de $\mathrm{Ba}, \mathrm{Y}, \mathrm{Rd}, \mathrm{Ni}$, Co y V son relativamente altas en los sedimentos del transecto de Guadalquivir. Las concentraciones de $\mathrm{Sr}$ se incrementan con la distancia a la costa, lo cual probablemente esté relacionado con el incremento de carbonato en los sedimentos. Según Machado et al. (2000b), el contenido de calcita de origen biogénico presenta una tendencia similar.
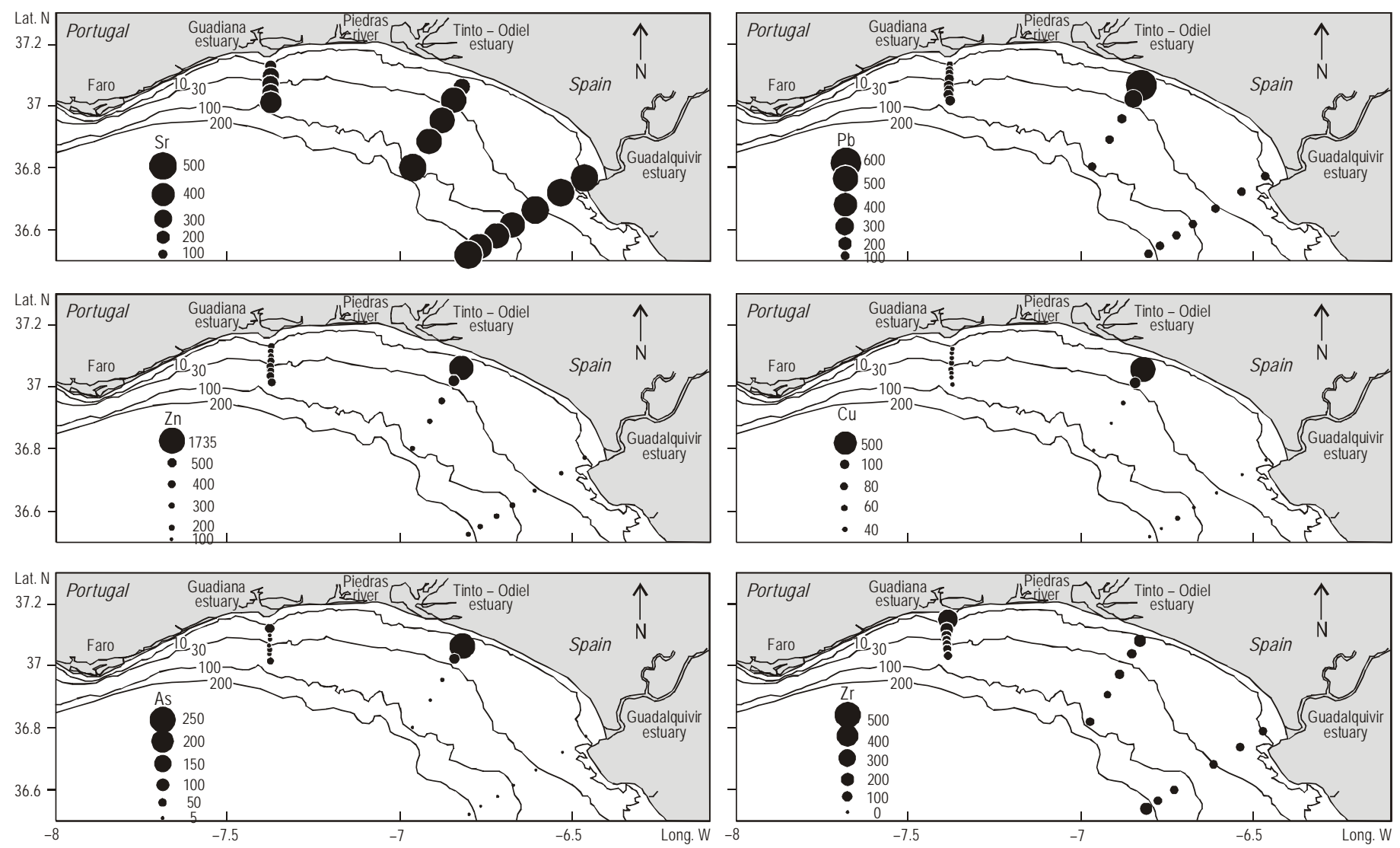

Figure 3. Concentrations of $\mathrm{Sr}, \mathrm{Pb}, \mathrm{Zn}, \mathrm{Cu}, \mathrm{As}$ and $\mathrm{Zr}$ in the surficial sediments of the sector of the continental shelf under study.

Figura 3. Concentraciones de $\mathrm{Sr}, \mathrm{Pb}, \mathrm{Zn}, \mathrm{Cu}, \mathrm{As}$ y $\mathrm{Zr}$ en los sedimentos superficiales de la sección de la plataforma continental estudiada. 

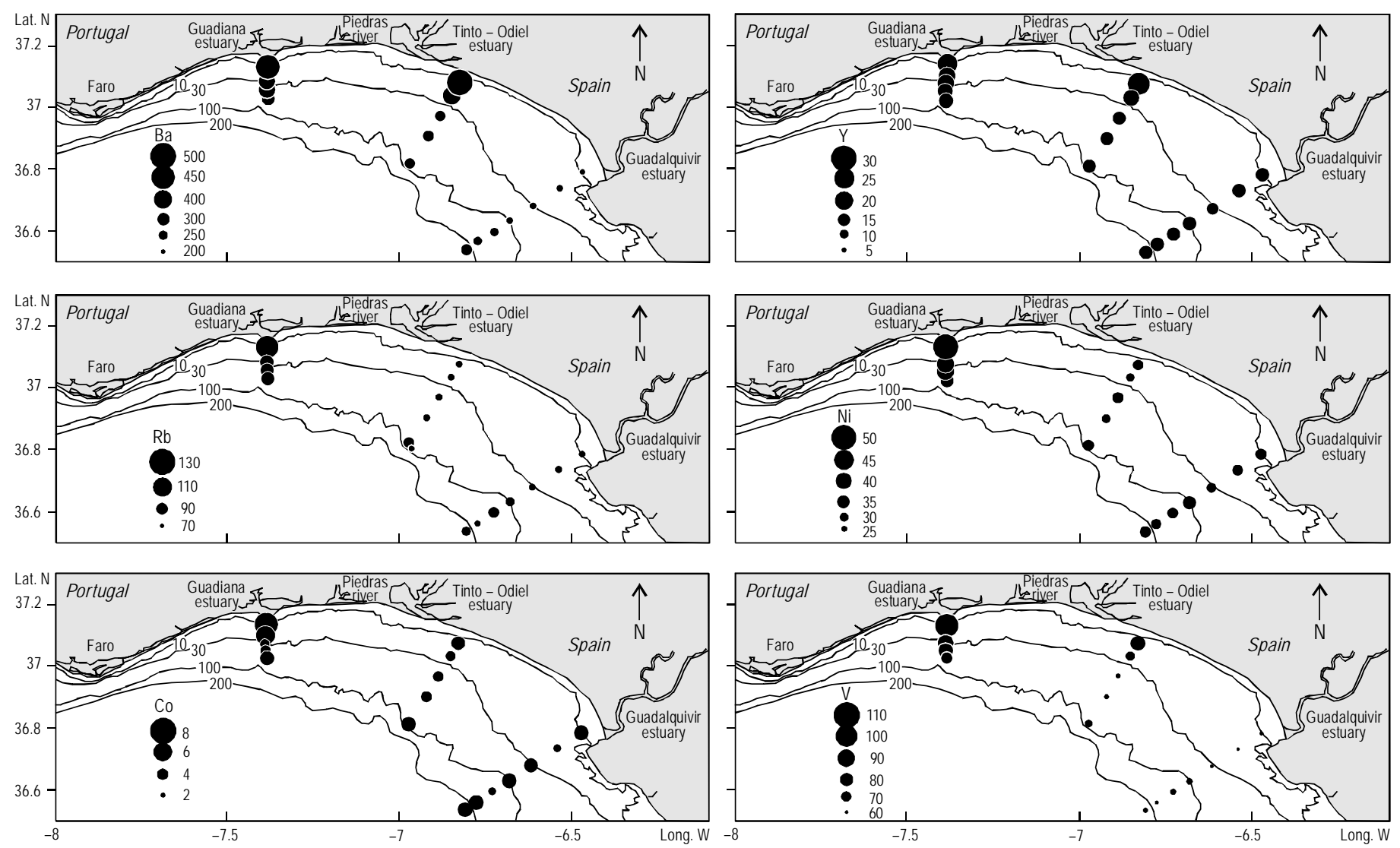

Figure 4. Concentrations of $\mathrm{Ba}, \mathrm{Y}, \mathrm{Rb}, \mathrm{Ni}, \mathrm{Co}$ and $\mathrm{V}$ in the surficial sediments of the sector of the continental shelf studied.

Figura 4. Concentraciones de $\mathrm{Ba}, \mathrm{Y}, \mathrm{Rb}, \mathrm{Ni}, \mathrm{Co}$ y $\mathrm{V}$ en los sedimentos superficiales de la sección de la plataforma continental estudiada.

Also, along the Guadiana transect, Ba, Y, Rb, Ni, Co and V concentrations decrease with the distance to the shore. This particular behaviour could be considered a signature of the Guadiana River. On the other hand, the highest Nb and Cr concentrations were found in sediments off the Guadiana estuary.

\section{Tinto-Odiel transect}

Off the Tinto-Odiel estuary, the shelf surficial sediments are highly polluted by heavy metals, such as $\mathrm{Cu}, \mathrm{Zn}$ and $\mathrm{Pb}$, associated with sulphide minerals coming in the outflows from sources in the Iberian Pyrite Belt and in the mineral wastes of industrial plants located near the estuarine border (Ruiz, 2001).

The Tinto-Odiel estuary seems to play an important role in the distribution of $\mathrm{Pb}, \mathrm{Zn}$, As and $\mathrm{Cu}$, the concentration of these elements becoming strongly reduced in the mid and outer zones of the continental shelf. Actually, the relatively high heavy metal concentrations in sediments of the Tinto-Odiel transect are most probably related to the mining activities taking place in the hinterland.

\section{Guadalquivir transect}

The concentrations of $\mathrm{Ba}, \mathrm{Y}, \mathrm{Rd}, \mathrm{Ni}, \mathrm{Co}$ and $\mathrm{V}$ are relatively high in sediments from the Guadalquivir transect. The concentrations of $\mathrm{Sr}$ increase with increasing distance
Asimismo, las concentraciones altas de Zn en los sedimentos de este transecto pueden estar relacionadas con el accidente ocurrido en la mina de zinc de Aznalcóllar (Andalucía, España) el 25 de abril de 1998. Este metal se encuentra predominantemente en la fracción más fina, i.e., la fracción arcillosa del sedimento.

En general, las concentraciones de todos los elementos traza mencionados disminuyen con la profundidad. Este patrón probablemente esté asociado con el comportamiento diferencial de las partículas de las fases minerales que contienen estos elementos durante los procesos hidraúlicos. Las concentraciones de $\mathrm{Pb}, \mathrm{Zn}$, As y $\mathrm{Cu}$ en los sedimentos seguramente están relacionadas con el Cinturón Pirítico, y sus valores pueden estar influenciados por las actividades industriales y mineras, mostrando concentraciones mayores en las desembocaduras de los ríos y menores lejos de la costa. El enriquecimiento en metales pesados ( $\mathrm{Pb}, \mathrm{Zn}$, As y $\mathrm{Cu}$ ) de la fracción fina de los sedimentos superficiales parece no exceder los $30 \mathrm{~m}$ de profundidad.

\section{Análisis estadístico multivariante}

El análisis de componentes principales (fig. 5) de los datos químicos obtenidos (REE y elementos traza) muestra que los parámetros químicos analizados están asociados en cuatro 
to the shore, which is possibly related to the increase of carbonate content in the sediments. According to Machado et al. (2000b), the calcite content of biogenic origin exhibits a similar trend.

Also, the high $\mathrm{Zn}$ concentrations determined in the sediments from this transect may be related to the environmental accident that occurred at the Aznalcóllar zinc mine (Andalucia, Spain), on 25 April 1998. This metal is predominantly fixed in the finest fraction, i.e., the clay fraction of the sediment.

In general, the concentrations of all the above-mentioned trace elements decrease with depth. This pattern is probably related to a differential behaviour in the hydraulic processes of the particles of the mineral phases containing these elements. The $\mathrm{Pb}, \mathrm{Zn}$, As and $\mathrm{Cu}$ concentrations determined in the sediments are surely related to the Pyrite Belt and their values may be influenced by industrial and mining activities, with the higher concentrations near the estuarine mouths and the lower concentrations far from the coastline. Enrichment of these heavy metals $(\mathrm{Pb}, \mathrm{Zn}, \mathrm{As}$ and $\mathrm{Cu})$ in the fine fraction of surficial sediment, seems not to exceed about $30 \mathrm{~m}$ depth.

\section{Multivariate statistical analysis}

The application of the principal components analysis (fig. 5) to the chemical data obtained (REE and trace elements) shows that the chemical parameters analyzed are associated in four sets. It was possible to extract three factors, with eigenvalues exceeding 1.0, explaining $89 \%$ of the total variance of the data set:

- Factor 1 (explaining 64\%) shows the first set of parameters: REE together with $\mathrm{Zn}, \mathrm{Cu}, \mathrm{Pb}, \mathrm{As}, \mathrm{Cr}, \mathrm{Ba}$ and $\mathrm{Y}$.

- Factor 2 (explaining 17\%) shows the second set of parameters: $\mathrm{Ni}, \mathrm{Rb}$ and $\mathrm{Nb}$.

- Factor 3 (explaining 8\%) shows $\mathrm{Zr}$ in opposition to Sr.

These distinct sets of chemical parameters may reflect distinct sources (lithogenic, biogenic and anthropogenic) of the elements, derived or not from the three estuaries considered. conjuntos. Fue posible extraer tres factores, con valores propios que exceden 1.0, y que explican $89 \%$ de la varianza total del conjunto de datos:

- El factor 1 explica 64\% y muestra el primer conjunto de parámetros: REE junto con $\mathrm{Zn}, \mathrm{Cu}, \mathrm{Pb}, \mathrm{As}, \mathrm{Cr}, \mathrm{Ba}$ y Y.

- El factor 2 explica 17\% y muestra el segundo conjunto de parámetros: Ni, Rb y Nb.

- $\quad$ El factor 3 explica 8\% y muestra el Zr opuesto al Sr.

Estos distintos conjuntos de parámetros químicos pueden reflejar diferentes fuentes (litogénica, biogénica y antropogénica) de los elementos, derivados o no de los tres estuarios considerados.

El primer conjunto de parámetros químicos probablemente sea una huella del Cinturón Pirítico, mientras que el segundo está relacionado con el material silicoclástico. Como se puede ver en la tabla 4, los tres elementos que forman el segundo conjunto (Ni, Rb y Nb) están fuertemente correlacionados con el Al. La discriminación ejercida por el factor 3 puede ser una consecuencia del tamaño de grano, estando el $\mathrm{Zr}$ presente en los minerales pesados (como circón) de metasedimentos ricos en biotitas y cloritas, mientras que el Sr se encuentra en los componentes biogénicos de los sedimentos.

\section{Razones geoquímicas}

La matriz de correlación (tabla 5) muestra la relación entre Al y elementos traza.

Según Martin y Meybeck (1979), al analizar la relación entre intemperismo y transporte fluvial, se define un factor de fraccionamiento con relación a un elemento conservativo, normalmente Al. Por tanto, los valores de los elementos traza se normalizaron, utilizando un elemento normativo (Al) asociado con los principales minerales que forman rocas (como los feldespatos). Este elemento que, por lo general, está enriquecido en las fracciones finas del sedimento, no es afectado significativamente por alteraciones antropogénicas (Ackerman, 1980).
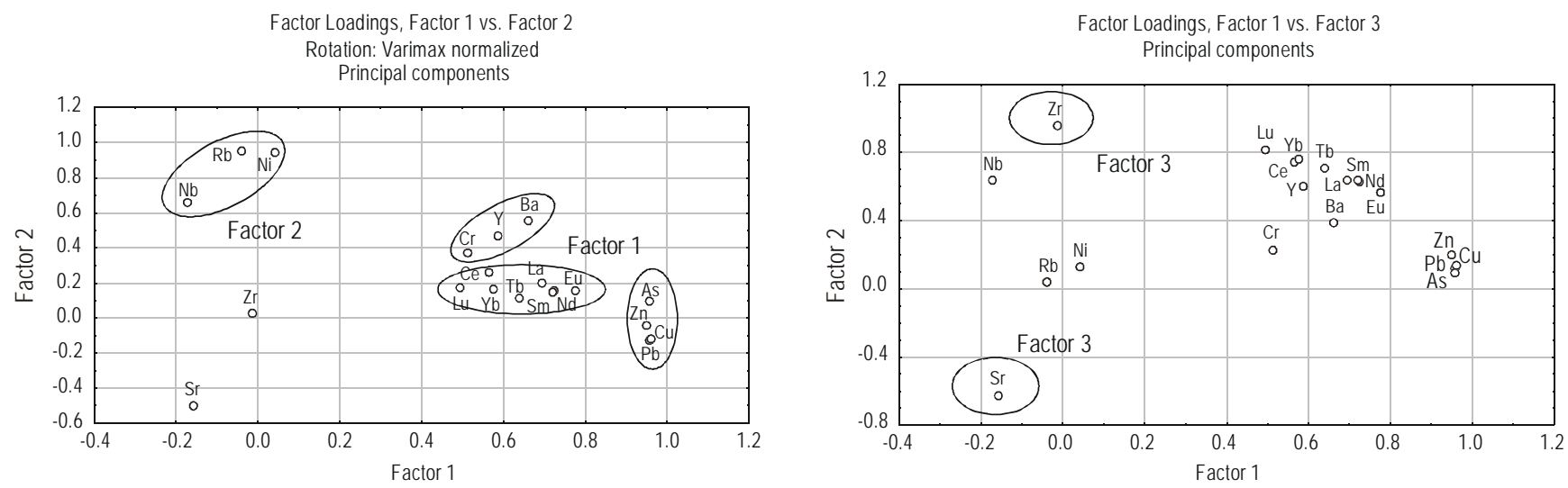

Figure 5. Factor loadings extracted by principal components analysis.

Figura 5. Cargas factoriales obtenidas mediante un análisis de componentes principales. 
The first set of chemical parameters is probably a signature of the Pyrite Belt, whereas the second set is related to the siliciclastic material. As can be seen from table 4, the three chemical elements forming the second set ( $\mathrm{Ni}, \mathrm{Rb}$ and $\mathrm{Nb}$ ) show high positive correlations with Al. The discrimination performed by factor 3 may be a consequence of grain size sorting, $\mathrm{Zr}$ being present in heavy minerals (like zircon) from biotite-chlorite rich metasediments, whereas $\mathrm{Sr}$ is present in the biogenic components of the sediments.

\section{Geochemical ratios}

Table 5, containing the correlation matrix, shows the relationship between $\mathrm{Al}$ and trace elements.

According to Martin and Meybeck (1979), when analyzing the relationship between weathering and river transport, a fractionation factor is defined with regard to a conservative element, usually Al. Therefore, trace element concentration values were normalized, using a normative element (Al) that is associated with the main rock-forming minerals (like feldspars). This element that, as a rule, is enriched in the sediment fine fractions, is not significantly affected by anthropogenic alterations (Ackerman, 1980).

A way of identifying the contamination is to correlate the normalized element (Al) and the assumed pollutant. When a linear relationship does not exist between both it is possible to attribute this situation to a polluting effect; this is the case of $\mathrm{Pb}, \mathrm{As}, \mathrm{Cu}$ and $\mathrm{Zn}$ (fig. 6). On the other hand, without anthropogenic disturbance that relationship is practically linear, as is the case of $\mathrm{Ba}, \mathrm{Nb}, \mathrm{Y}, \mathrm{Rb}$ and $\mathrm{Ni}$ (table 5).
Una forma de identificar la contaminación es correlacionar el elemento normalizado ( $\mathrm{Al}$ ) y el supuesto contaminante. Cuando no existe una relación lineal entre ambos es posible atribuir esta situación a un efecto de contaminación; tal es el caso de $\mathrm{Pb}$, As, Cu y Zn (fig. 6). Por otro lado, sin perturbación antropogénica, esa relación es prácticamente lineal, como es el caso de $\mathrm{Ba}, \mathrm{Nb}, \mathrm{Y}, \mathrm{Rb}$ y Ni (tabla 5).

En términos generales las concentraciones de metales pesados están controladas geológicamente, siendo sus fuentes las cuencas de drenaje de los ríos. Sin embargo, en algunas muestras del transecto de Tinto-Odiel resulta posible identificar algunas contribuciones antropogénicas de $\mathrm{Pb}, \mathrm{As}, \mathrm{Zn}$ y Cu, cuyas concentraciones son relativamente mayores no sólo que la concentración media respectiva de los sedimentos analizados, sino también que los patrones de referencia (Turekian y Wedepohl, 1961; Mason y Moore, 1982). De acuerdo con Martin y Meybeck (1979), algunos elementos (como Br, Sb, $\mathrm{Pb}, \mathrm{Cu}, \mathrm{Mo}, \mathrm{Zn}$ y $\mathrm{Ni}$ ) muestran enriquecimiento en relación con el Al, mientras que otros elementos menos movilizados (como REE, Co, Cr, Cs, Mn, Rb, Si, Th, Ti, U y V) no muestran ningún enriquecimiento natural y otros (como B, Ba, Ca, $\mathrm{K}, \mathrm{Mg}$, Na y Sr) muestran una reducción relativa.

$\mathrm{El} \mathrm{Al}$ parece estar relacionado directamente con $\mathrm{Ba}, \mathrm{Nb}, \mathrm{Y}$, $\mathrm{Rb}$ y Ni e indirectamente con Sr. La normalización geoquímica basada en el $\mathrm{Al}$, para estas concentraciones de los metales traza, indica una fuente litogénica de los elementos mencionados (fig. 7).

En la figura 8 se muestra la distribución de los elementos traza $\mathrm{Ba}, \mathrm{Nb}, \mathrm{Y}, \mathrm{Rb}, \mathrm{Ni}$ y $\mathrm{Sr}$ (todos normalizados en relación con $\mathrm{Al}$ ), en las muestras de sedimento de los tres transectos.

Table 5. Correlation matrix of Al and trace elements.

Tabla 5. Matriz de correlación entre Al y elementos traza.

\begin{tabular}{|c|c|c|c|c|c|c|c|c|c|c|c|c|c|c|}
\hline & Al & Ba & Nb & $\mathrm{Zr}$ & $\mathbf{Y}$ & Sr & $\mathbf{R b}$ & $\mathbf{P b}$ & As & Zn & $\mathbf{C u}$ & $\mathbf{N i}$ & Co & $\mathrm{Cr}$ \\
\hline Al & 1.0 & & & & & & & & & & & & & \\
\hline Ba & 0.8 & 1.0 & & & & & & & & & & & & \\
\hline Nb & 0.8 & 0.5 & 1.0 & & & & & & & & & & & \\
\hline $\mathrm{Zr}$ & 0.4 & 0.4 & 0.6 & 1.0 & & & & & & & & & & \\
\hline $\mathbf{Y}$ & 0.8 & 0.9 & 0.6 & 0.6 & 1.0 & & & & & & & & & \\
\hline Sr & -0.7 & -0.6 & -0.7 & -0.6 & -0.7 & 1.0 & & & & & & & & \\
\hline $\mathbf{R b}$ & 0.9 & 0.5 & 0.7 & 0.1 & 0.5 & -0.4 & 1.0 & & & & & & & \\
\hline $\mathbf{P b}$ & 0.1 & 0.6 & -0.2 & 0.1 & 0.6 & -0.2 & -0.2 & 1.0 & & & & & & \\
\hline As & 0.3 & 0.7 & 0.0 & 0.1 & 0.7 & -0.3 & 0.1 & 0.9 & 1.0 & & & & & \\
\hline Zn & 0.2 & 0.7 & 0.0 & 0.2 & 0.7 & -0.3 & -0.1 & 1.0 & 1.0 & 1.0 & & & & \\
\hline $\mathrm{Cu}$ & 0.1 & 0.6 & -0.1 & 0.1 & 0.6 & -0.2 & -0.2 & 1.0 & 1.0 & 1.0 & 1.0 & & & \\
\hline $\mathbf{N i}$ & 0.9 & 0.6 & 0.7 & 0.2 & 0.6 & -0.5 & 1.0 & -0.1 & 0.2 & 0.0 & 0.0 & 1.0 & & \\
\hline Co & 0.2 & 0.2 & 0.1 & -0.1 & 0.1 & -0.2 & 0.3 & 0.0 & 0.2 & 0.0 & 0.0 & 0.3 & 1.0 & \\
\hline $\mathrm{Cr}$ & 0.5 & 0.6 & 0.2 & 0.3 & 0.5 & -0.8 & 0.3 & 0.5 & 0.6 & 0.5 & 0.5 & 0.3 & 0.4 & 1.0 \\
\hline
\end{tabular}

Values with high correlation in bold. 

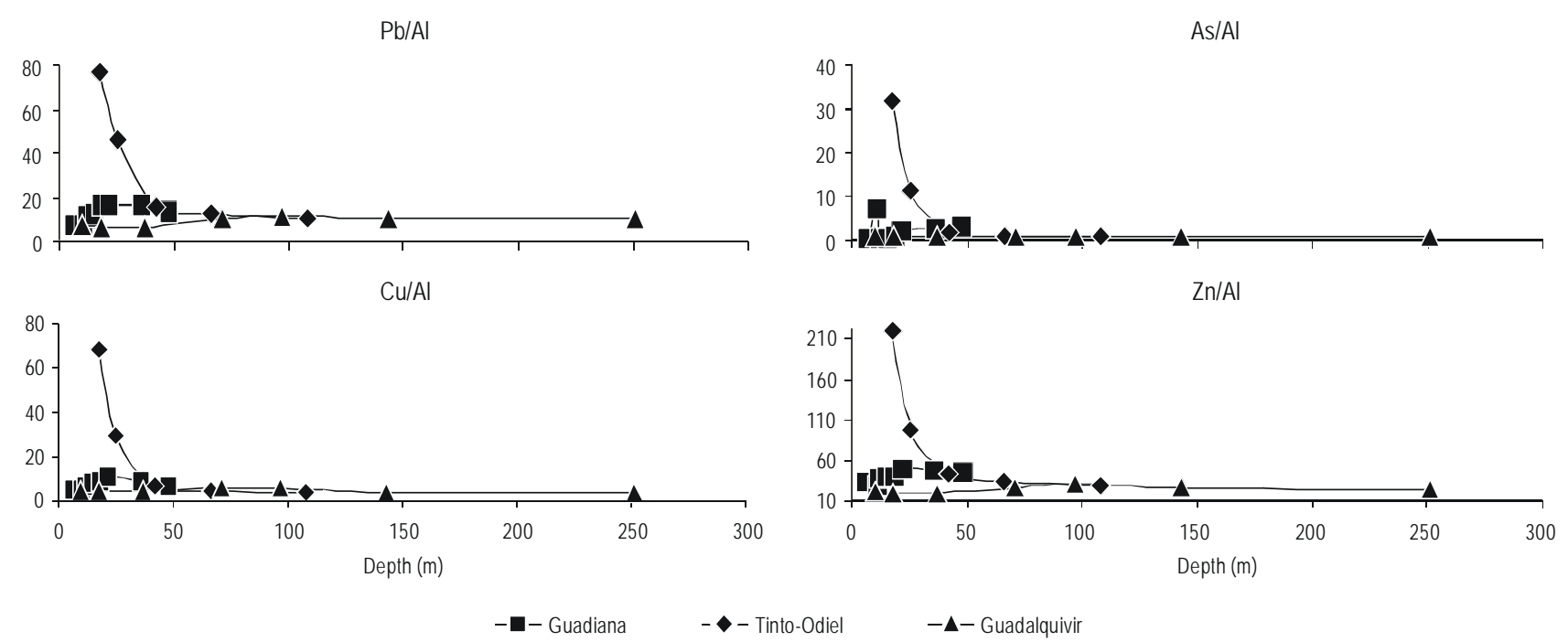

Figure 6. Variation of the $\mathrm{Pb} / \mathrm{Al}, \mathrm{As} / \mathrm{Al}, \mathrm{Zn} / \mathrm{Al}$ and $\mathrm{Cu} / \mathrm{Al}$ ratios in the transects.

Figura 6. Variación de las razones $\mathrm{Pb} / \mathrm{Al}, \mathrm{As} / \mathrm{Al}, \mathrm{Zn} / \mathrm{Al}$ y $\mathrm{Cu} / \mathrm{Al}$ en los transectos.

In general terms, heavy metal concentrations are geologically controlled, their sources being the drainage basins of the rivers. However, in some samples belonging to the transect off the Tinto-Odiel estuary, it is possible to identify some anthropogenic contributions of $\mathrm{Pb}, \mathrm{As}, \mathrm{Zn}$ and $\mathrm{Cu}$, whose concentrations are relatively higher not only than the respective average concentration of the sediments analyzed but also than the reference patterns (Turekian and Wedepohl, 1961; Mason and Moore, 1982). According to Martin and Meybeck (1979), some elements (like $\mathrm{Br}, \mathrm{Sb}, \mathrm{Pb}, \mathrm{Cu}, \mathrm{Mo}, \mathrm{Zn}$ and $\mathrm{Ni}$ ) show enrichment relative to $\mathrm{Al}$, whereas some less mobilized elements (like REE, Co, Cr, Cs, Mn, Rb, Si, Th, Ti, U and V) show no natural enrichment and others (like B, Ba, Ca, K, Mg, $\mathrm{Na}$ and $\mathrm{Sr}$ ) show relative depletion.

Aluminium seems to be related directly to $\mathrm{Ba}, \mathrm{Nb}, \mathrm{Y}, \mathrm{Rb}$ and $\mathrm{Ni}$ and indirectly to Sr. The geochemical normalization, based on $\mathrm{Al}$, for these trace element concentrations points to the lithogenic source of the elements referred to (fig. 7).

Figure 8 shows the distribution of the following trace elements in the sediment samples of the three transects: $\mathrm{Ba}, \mathrm{Nb}, \mathrm{Y}$, $\mathrm{Rb}$, Ni and $\mathrm{Sr}$ (all Al normalized).

\section{REE distribution}

Rare earth elements (REE) occur as trace elements in all types of rocks (sedimentary, igneous or metamorphic) and exhibit a tendency to be concentrated in accessory rockforming minerals such as titanite, apatite, zircon, epidote, garnet and clay minerals. Because REE are not easily fractionated during sedimentation, sedimentary REE patterns may provide information about the sediment provenance.

The distribution of REE in the sediments of the three transects studied is shown in figure 9. Comparing the three transects, REE distribution patterns show lower REE contents

\section{Distribución de REE}

Los REE aparecen como elementos traza en todo tipo de rocas (sedimentaria, ígnea o metamórfica) y exhiben una tendencia a concentrarse en minerales que forman rocas accesorias como titanita, apatita, circón, epidota, granate y minerales arcillosos. En vista de que los REE no se fraccionan fácilmente durante la sedimentación, los patrones sedimentarios de los REE pueden proveer información sobre el origen de los sedimentos.

La distribución de los REE en los sedimentos de los tres transectos estudiados se muestra en la figura 9. Al comparar los tres transectos, los patrones de distribución de REE muestran contenidos menores en los sedimentos del transecto de Guadalquivir, lo cual se puede deber a dilución por carbonato biogénico.

Existen contenidos particularmente altos de REE en los sedimentos del transecto de Tinto-Odiel localizados cerca de la costa, los cuales disminuyen rápidamente con la profundidad.

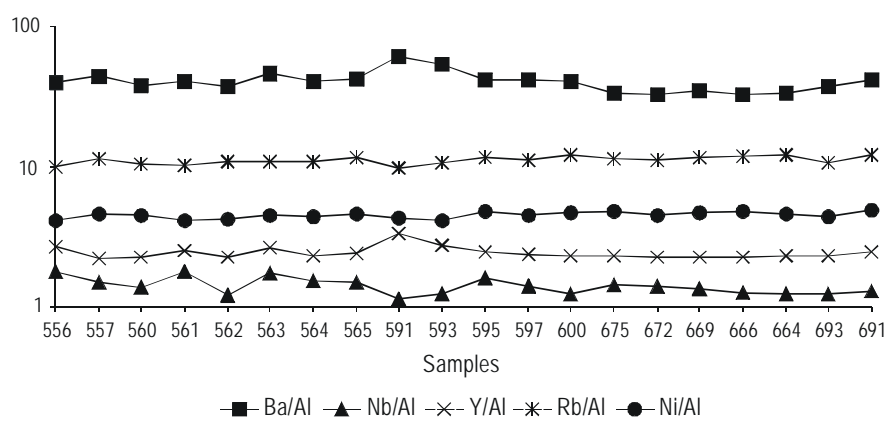

Figure 7. Variation of the $\mathrm{Ba} / \mathrm{Al}, \mathrm{Nb} / \mathrm{Al}, \mathrm{Y} / \mathrm{Al}, \mathrm{Rb} / \mathrm{Al}$ and Ni/Al ratios in the transects.

Figura 7. Variación de las razones Ba/Al, Nb/Al, Y/Al, Rb/Al y Ni/Al en los transectos. 

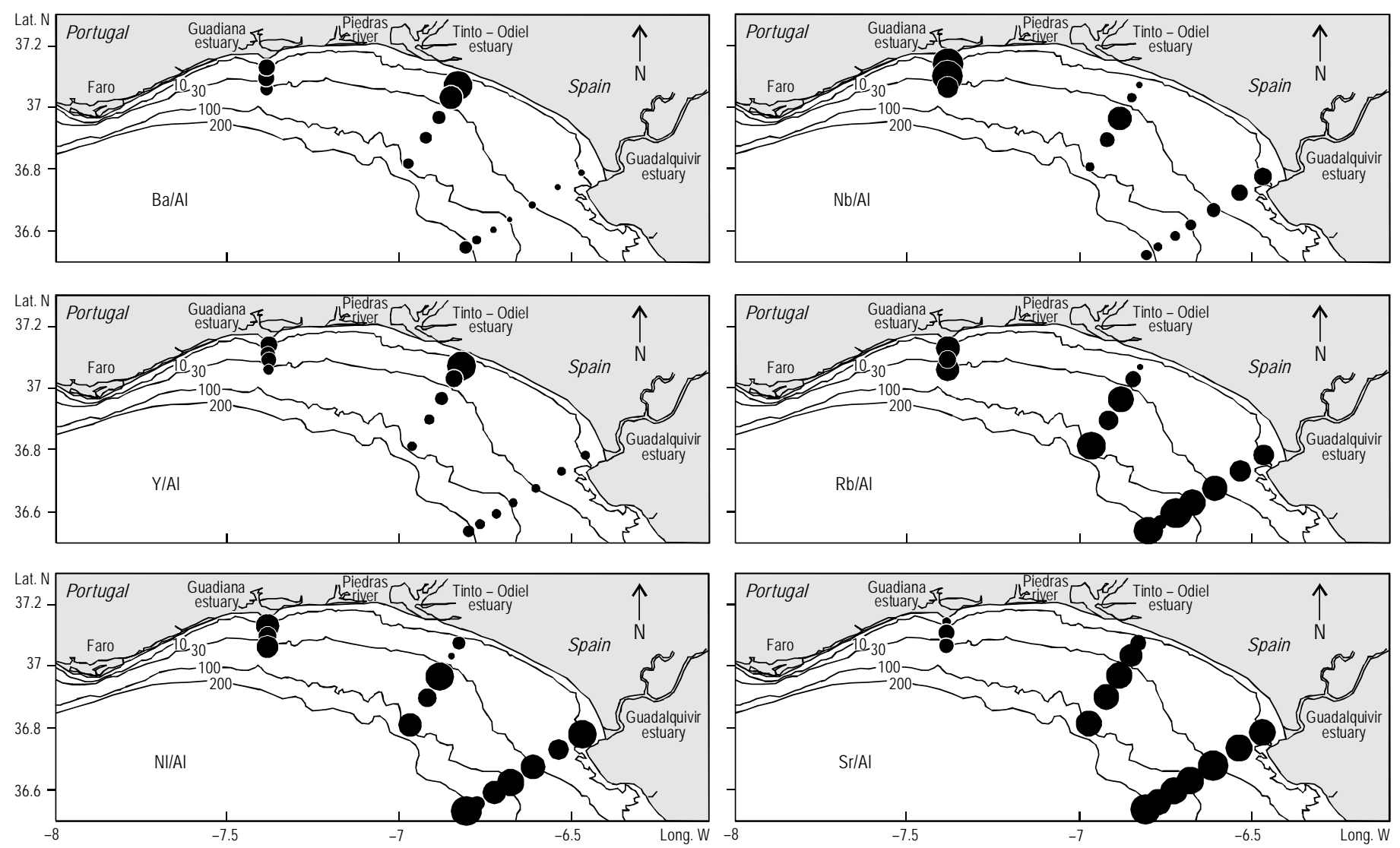

Figure 8. Distribution of $\mathrm{Ba}, \mathrm{Nb}, \mathrm{Y}, \mathrm{Rb}, \mathrm{Ni}$ and $\mathrm{Sr}$ (all Al normalized) in the sediments of the three transects.

Figura 8. Distribución de $\mathrm{Ba}, \mathrm{Nb}, \mathrm{Y}, \mathrm{Rb}, \mathrm{Ni}$ y $\mathrm{Sr}$ (todos normalizados a Al) en los sedimentos de los tres transectos.

in sediments from the Guadalquivir transect, which could be due to dilution by biogenic carbonate.

Particularly high REE contents exist in the sediments of the Tinto-Odiel transect positioned close to the coastline, the contents decreasing rapidly with depth. Differently, in sediments from the Guadiana transect, REE contents gradually decrease with depth. The deposit of REE-rich minerals such as heavy minerals and clay minerals close to the Tinto-Odiel and Guadiana coastlines might explain these variations.

Figure 10 shows the presence of a muddy formation located approximately between the bathymetric lines of 30 and $100 \mathrm{~m}$ depth, in a zone off and limited by the Guadiana and Guadalquivir estuaries. Plumes provenance from the three estuaries studied could also be identified, especially in the Guadalquivir. High organic matter concentration near the Guadalquivir outlet corresponds to fine-grained sediments, and may be related to the local hydrodynamic regime.

Figure 11 shows the shale-normalized REE plot of the surficial sediments $(<38 \mu \mathrm{m}$ fractions) in each transect (Guadiana, Tinto-Odiel and Guadalquivir estuaries): the concentration of the individual REE in the sediment divided by the concentration in the NASC reference material (Taylor and McLennan, 1988). In general terms, a negative anomaly of Ce does exist, whereas Sm, followed by La, are the more enriched REE in this fraction.
Por lo contrario, los contenidos de REE en los sedimentos del transecto de Guadiana disminuyen gradualmente con la profundidad. El depósito de minerales ricos en REE como minerales pesados y arcillosos cerca de las costas de TintoOdiel y Guadiana podría explicar estas variaciones.

La figura 10 muestra la presencia de una formación limosa localizada aproximadamente entre las líneas batimétricas de 30 y $100 \mathrm{~m}$ de profundidad, en una zona enfrente de y limitada por

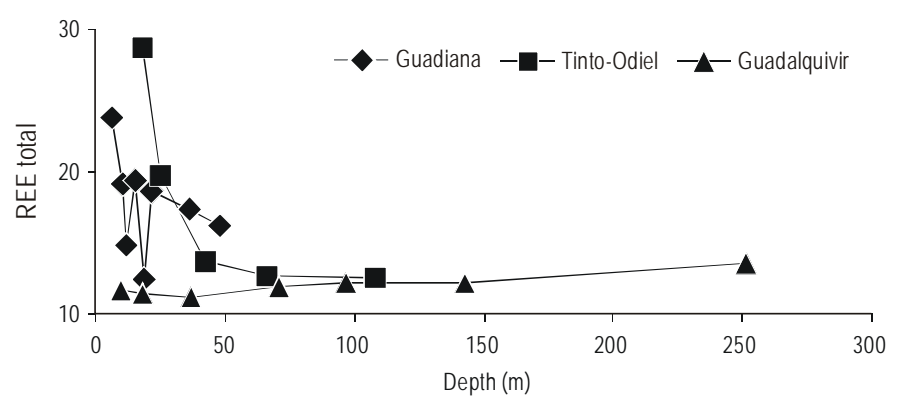

Figure 9. Distribution of $\Sigma$ rare earth elements (REE) in sediments of the transects off the Guadiana, Tinto-Odiel and Guadalquivir estuaries.

Figura 9. Distribución de los $\Sigma$ elementos del grupo de las tierras raras (REE) en los sedimentos de los transectos frente a los estuarios de Guadiana, Tinto-Odiel y Guadalquivir. 


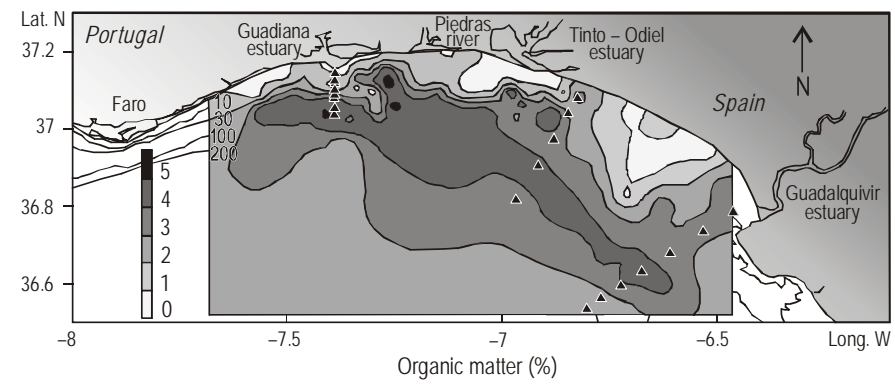

Figure 10. Distribution pattern of the organic matter concentration.

Figura 10. Patrón de distribución de la concentración de materia orgánica.

The behaviour of the REE in the transect off the Guadiana estuary reveals that Ce presents a weak negative anomaly compared to the other two transects; on the other hand, it presents higher concentrations of Sm. In the case of the Tinto-Odiel transect, REE distribution curves are characterized by higher concentrations close to the coastline, a negative anomaly for $\mathrm{Ce}$, a positive anomaly for $\mathrm{Eu}$ and low REE contents in the sediments located far away from the coastline. The Guadalquivir transect is characterized by low REE contents, compared to the other two transects, and a pronounced negative anomaly for Ce.

Figure 12 exhibits the variation of LREE and HREE (light and heavy RRE, respectively), using the La/Yb curve (Haskin, 1971) and the Ce anomaly, expressed by the $\mathrm{Ce} / \mathrm{Ce}^{*}$ ratio (Boust, 1986; $\left.\mathrm{Ce}^{*}=3 \times \mathrm{Ce} /[(2 \times \mathrm{La})+\mathrm{Nd}]\right)$ in the sediments studied. The La/Yb ratio exhibits a more pronounced LREE enrichment relative to HREE from east to west. los estuarios de Guadiana y Guadalquivir. También se pudo identificar el origen de plumas de los tres estuarios, especialmente en el Guadalquivir. La elevada concentración de material orgánico cerca de la desembocadura del río Guadalquivir corresponde a sedimentos de grano fino y puede estar relacionada con el régimen hidrodinámico local.

La figura 11 muestra la gráfica de los REE normalizados a lutita de los sedimentos superficiales (fracciones $<38 \mu \mathrm{m}$ ) en cada transecto (Guadiana, Tinto-Odiel y Guadalquivir): la concentración de los REE individuales en el sedimento dividida entre la concentración del material de referencia NASC (Taylor y McLennan, 1988). En general, existe una anomalía negativa de Ce, mientras que Sm, seguido por La, son los REE más enriquecidos de esta fracción.

El comportamiento de los REE en el transecto de Guadiana muestra una anomalía negativa débil de Ce en comparación con los otros dos transectos y, por otro lado, concentraciones mayores de Sm. En el caso del transecto de Tinto-Odiel, las curvas de distribución de REE se caracterizan por concentraciones mayores cerca de la costa, una anomalía negativa de Ce, una anomalía positiva de Eu y bajos contenidos de REE en los sedimentos localizados lejos de la costa. El transecto de Guadalquivir se caracteriza por bajos contenidos de REE en comparación con los otros dos transectos, y una pronunciada anomalía negativa de Ce.

La figura 12 muestra la variación de LREE y HREE (REE ligeros y pesados, respectivamente), usando la curva de $\mathrm{La} / \mathrm{Yb}$ (Haskin, 1971) y la anomalía de Ce, expresada por la razón de Ce/Ce* (Boust, 1986; Ce* $=3 \times \mathrm{Ce} /[(2 \times \mathrm{La})+\mathrm{Nd})$ en los
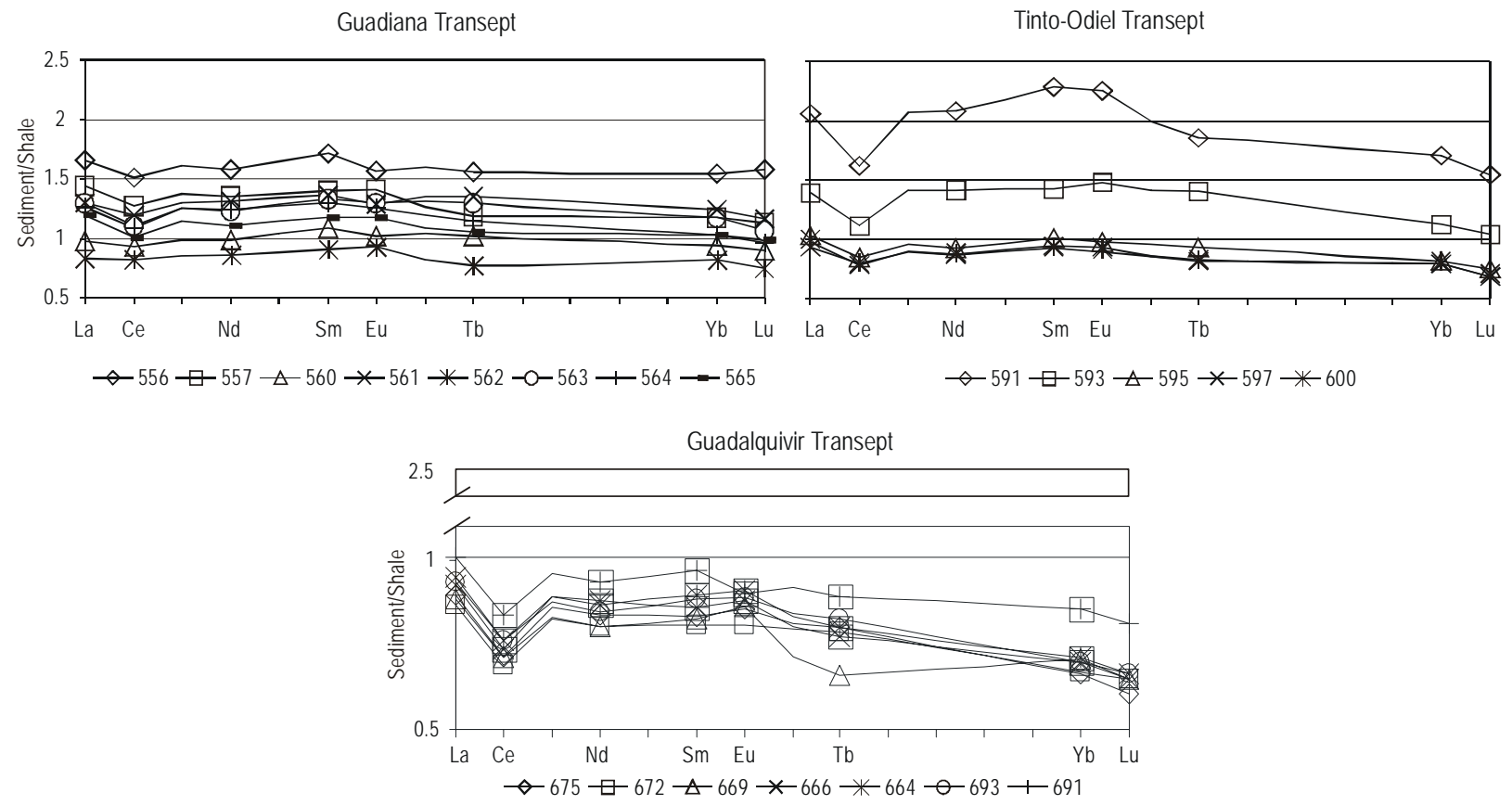

Figure 11. Shale-normalized rare earth elements (REE/shale) concentrations in the surficial sediments of the three transects (Guadiana, Tinto-Odiel and Guadalquivir).

Figura 11. Concentraciones de los elementos del grupo de las tierras raras normalizadas a lutita (REE/shale) en los sedimentos superficiales de los tres transectos (Guadiana, Tinto-Odiel y Guadalquivir). 


\section{Final considerations}

The geochemical characterization of surficial sediments from the southwestern Iberian continental shelf, comprising 22 trace elements (REE included) quantified along three transects off the Guadiana, Tinto-Odiel and Guadalquivir estuaries, allowed the distribution patterns characteristic of those transects to be established; hence, it was possible to define in those sediments signatures attributed to the influence of the rivers referred to.

For the transect off the Guadiana estuary, where $\mathrm{Pb}, \mathrm{As}, \mathrm{Zn}$, $\mathrm{Cu}$ and $\mathrm{Co}$ anomalies were found, the concentration of these elements becomes slightly higher as the distance to the coastline increases, and a similar tendency is shown by the organic matter concentration. Marine clays commonly show enrichment, relative to river particulate matter, in $\mathrm{Cu}$ and As but not in $\mathrm{Zn}, \mathrm{Pb}$ and $\mathrm{Co}$. Therefore, the supply of fresh particulate and organic matter appears to play an important role in the fixation of those heavy metals.

For the transect off the Tinto-Odiel estuary, extremely high accumulations of $\mathrm{Pb}, \mathrm{Zn}$ and $\mathrm{Cu}$ were found close to the river outlet; these heavy metal concentrations are most probably related to mining and other industrial activities.

For the transect off the Guadalquivir estuary, the concentrations of all the trace elements analyzed show the highest values both in the middle and outer shelf, to some extent due to grain size control. The relatively higher $\mathrm{Sr}$ and $\mathrm{Ba}$ concentrations are directly correlated to the relatively higher carbonate content in the sediments.

As a rule, REE contents in the shelf surficial sediments decrease with the distance to the coastline, a fact most probably related to the change of a prevailing detrital sedimentation near the coast to a relatively more dominant chemical sedimentation far from the coast. The strong Ce negative anomaly is indicative of a more hydrogenized environment in the sediment-seawater interface.

Concerning the distinction between sediments from the Guadiana, Tinto-Odiel and Guadalquivir transects with regard to REE contents, the lower values found in the Guadiana transect could be related to the lower clay fraction content in the sediments, reflected in the less fixation ability of REE by the sediments. The same situation was found for the Guadalquivir transect. On the other hand, the relatively higher REE contents found in sediments from the Tinto-Odiel transect could be related to the higher clay fraction contents in those sediments.

The Guadiana sediments present a low content of REE and show relatively flat patterns, arguing for the importance of detrital material in these samples. That is also the case for the Guadalquivir transect. The REE profiles of the samples from the Guadalquivir transect are extremely similar to each other. This homogeneity tends to indicate that these samples have the same origin. For Tinto-Odel, a higher REE concentration and a clear Ce anomaly are noticeable in samples 593 and 597. This may be related to an increase of authigenic minerals formed in

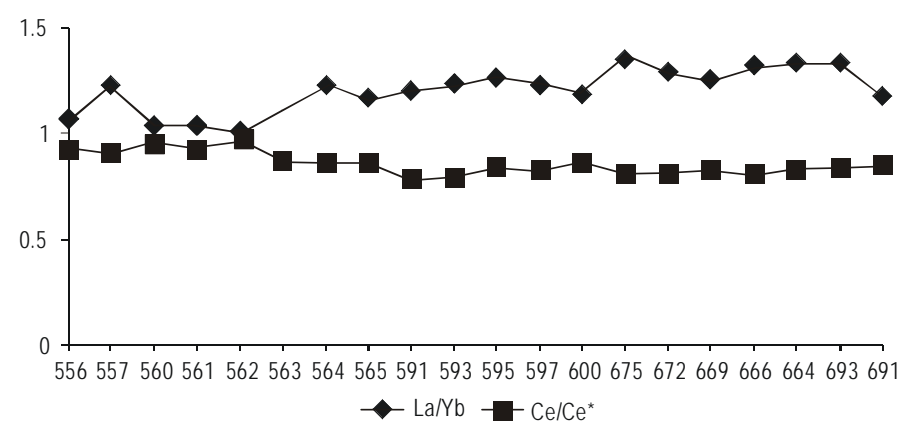

Figure 12. Variation of $\mathrm{La} / \mathrm{Yb}$ and $\mathrm{Ce} / \mathrm{Ce}^{\star}$ ratios in the surficial sediments of the transects off the Guadiana, Tinto-Odiel and Guadalquivir estuaries.

Figura 12. Variación de las razones de La/Yb y Ce/Ce* en los sedimentos superficiales de los transectos frente a los estuarios de Guadiana, TintoOdiel y Guadalquivir.

sedimentos estudiados. La razón de La/Yb presenta un enriquecimiento más pronunciado de LREE en relación con HREE de este a oeste.

\section{Consideraciones finales}

La caracterización geoquímica de sedimentos superficiales del sudoeste de la plataforma continental ibérica, considerando 22 elementos traza (incluyendo los REE) cuantificados a lo largo de tres transectos frente a los estuarios de Guadiana, Tinto-Odiel y Guadalquivir, permitió establecer los patrones de distribución característicos de estos transectos; por tanto, fue posible definir huellas en esos sedimentos atribuibles a los ríos mencionados.

Para el transecto de Guadiana, donde se encontraron anomalías de $\mathrm{Pb}, \mathrm{As}, \mathrm{Zn}, \mathrm{Cu}$ y Co, la concentración de estos elementos aumenta ligeramente conforme aumenta la distancia a la costa; la concentración de materia orgánica muestra un patrón similar. Las arcillas marinas comúnmente muestran enriquecimiento de $\mathrm{Cu}$ y As con respecto al material particulado de ríos, pero no así de $\mathrm{Zn}, \mathrm{Pb}$ y Co. Por tanto, el suministro de material particulado y orgánico nuevo parece jugar un papel importante en la fijación de esos metales pesados.

Para el transecto de Tinto-Odiel, se encontraron acumulaciones extremadamente altas de $\mathrm{Pb}, \mathrm{Zn}$ y $\mathrm{Cu}$ cerca de la desembocadura. Estas concentraciones de metales pesados probablemente estén relacionadas con actividades industriales y mineras.

Para el transecto de Guadalquivir, las concentraciones de todos los elementos traza analizados muestran los valores más altos tanto en la plataforma media como en la exterior, hasta cierto punto debido al tamaño de grano. Las concentraciones relativamente mayores de Sr y Ba están directamente correlacionadas con el contenido relativamente mayor de carbonato en los sedimentos.

Los contenidos de REE en los sedimentos superficiales de la plataforma continental decrecen con la distancia a la costa, 
the seawater, or to the occurrence of biogenic material. Curiously, the drop in quartz abundance between the Guadiana transect and both the Tinto-Odiel and Guadalquivir ones did not affect the REE profiles, whereas usually, a high quartz content dilutes the concentration of REE in sediments.

\section{Acknowledgements}

The present work was carried out within the framework of the following projects: SIRIA (Situação de Referência na Região Costeira Algarvia Influenciável pela Barragem de Alqueva); Ambiente e Defesa of the National Ministry of Defense and the Foundation of Portuguese Universities; EMERGE (Estudo Multidisciplinar do Estuário do Rio Guadiana), ODIANA and CRIDA (Consequences of River Discharge Modifications on Coastal Zone and Continental Shelf) (PLE/8/00). The first author thanks Carlos Galhano of the Nova University of Lisbon, the CIACOMAR research team of the University of Algarve, especially Ramón González, and the Foundation of Science and Technology (FCT).

\section{References}

Ackermann, F. (1980). A procedure for correcting the grain size effect in heavy metal analyses of estuarine and coastal sediments. Environ. Techonol. Lett., 1: 520-527.

Boust D. (1986). Les terres rares au cours de la diagenèse des sediments abyssaux; analogies avec un transuranien. L’Americium. Ph.D. thesis, Univ. Caen, France.

Cabrera, F., Conde, B. and Flores, V. (1992). Heavy metals in the surface sediments of the tidal river Tinto (SW Spain). Fresenius Environ. Bull., 1: 400-405.

Chamley, H. (1989). Clay Sedimentology. Springer-Verlag, 623 pp.

Drago, T., Naughton, F., Moreno, J., Rocha, F., Cachão, M., Sanchez Gõni, M.F., Oliveira, A., Cascalho, J., Fatela, F., Freitas, C. and Andrade, C. (2002). Geological record of environmental changes in the Douro Estuary (NW Portugal): Since the Late Glacial. Proc. Littoral'2002, 6th EUROCOAST International Conference, III, pp. 341-346.

Elbaz-Poulichet, F., Morley, N.H., Beckers, J.M. and Nomerange, P. (2001). Metal fluxes through the Strait of Gibraltar: The influence of the Tinto and Odiel rivers (SW Spain). Mar. Chem., 73: 193-213.

Gouveia, M.A. and Prudêncio, M.I. (2000). New data on sixteen reference material obtained by INAA. J. Radioanal. Nucl. Chem., 245: 105-108.

Ferreira, A. (2000). Dados geoquímicos de base de sedimentos fluviais de amostragem de baixa densidade de Portugal Continental: Estudos de factores de variação regional. Ph.D. thesis, Univ. Aveiro, Portugal.

Haskin, L.A., Haskin, M.A., Frey, F.A. and Wildeman, T.R. (1968). Relative and absolute terrestrial abundances of the rare earths. In: L.H. Ahrens (ed.), Origin and Distribution of the Elements. Pergamon Press, 2, pp. 889-911.

Haskin, L.A., Helmke, P.A., Paster, T.P. and Allen, R.O. (1971). Activation analysis. In: A.O. Brunfelt and E. Steinnes (eds.), Geochemistry and Cosmochemistry. Universitetsforlaget, Oslo, pp. 201-218.

Machado, A., Rocha, F. and Gomes, C. (1999a). Statistical analysis of mineralogical parameters used as lithostratigraphic markers. Application to Quaternary sediments of the littoral between hecho que probablemente se relacione con el cambio de una sedimentación detrítica prevaleciente cerca de la costa a una sedimentación más química lejos de ésta. La fuerte anomalía negativa de Ce es un indicio del ambiente más hidrogenizado en la zona de contacto entre sedimento y agua de mar.

Con respecto a la distinción entre los sedimentos de los transectos de Guadiana, Tinto-Odiel y Guadalquivir en cuanto a los contenidos de REE, los valores menores encontrados en el transecto de Guadiana pueden estar relacionados con su menor contenido en la fracción arcillosa de los sedimentos, lo que se refleja en una menor capacidad de los sedimentos para fijar REE. Esta misma situación se encontró en el transecto de Guadalquivir. Por otro lado, los contenidos relativamente mayores de REE en los sedimentos del transecto de TintoOdiel pueden estar relacionados con los contenidos mayores en la fracción arcillosa de esos sedimentos.

Los sedimentos de Guadiana presentan un contenido bajo de REE y muestran patrones relativamente uniformes, por lo que se podría argüir la importancia del material detrítico en estas muestras. Éste también es el caso para el transecto de Guadalquivir. Los perfiles de REE de las muestras del transecto de Guadalquivir son extremadamente similares uno al otro. Esta homogeneidad parece indicar un mismo origen de las muestras. Para Tinto-Odel se aprecian una mayor concentración de REE y una clara anomalía de Ce en las muestras 593 y 597. Esto puede estar relacionado con un aumento en los minerales autigénicos formados en el agua de mar, o con la ocurrencia de material biogénico. Curiosamente, la caída en la abundancia de cuarzo entre el transecto de Guadiana y los de Tinto-Odiel y Guadalquivir no afectó los perfiles de REE, mientras que, usualmente, un elevado contenido de cuarzo diluye la concentración de REE en los sedimentos.

\section{Agradecimientos}

Este trabajo se realizó como parte de los proyectos: SIRIA (Situação de Referência na Região Costeira Algarvia Influenciável pela Barragem de Alqueva); Ambiente e Defesa del Ministerio de Defensa Nacional y la Fundación de Universidades Portuguesas; EMERGE (Estudo Multidisciplinar do Estuário do Rio Guadiana), ODIANA y CRIDA (Consequences of River Discharge Modifications on Coastal Zone and Continental Shelf) (PLE/8/00). El primer autor agradece a Carlos Galhano de la Universidad Nova de Lisboa, al equipo de investigación CIACOMAR de la Universidad de Algarve, en especial a Ramón González, y a la Fundación para la Ciencia y Tecnología (FCT).

Traducido al español por Christine Harris.

Espinho and Furadouro (Portugal). Bol. Inst. Esp. Oceanogr., 15(1-4): 303-312.

Machado, A., Silva, A.P., Rocha, F. and Gomes, C. (1999b). Heavy metals versus clay minerals in the Quaternary sediments of the Cortegaça beach formation (Ovar, Portugal). Estudos do Quaternário, Rev. Ass. Port. Est. Quatern., 2: 19-25. 
Machado, A., Rocha, F., Dias, A. and Gomes, C. (2000a). Distribution patterns of clay minerals in the surficial sediments of the continental shelf off Guadiana estuary (Algarve, Portugal): Preliminary study. Proc. 1st Latin American Clay Conference, Ass. Port. Argilas, 2: 64-68.

Machado, A., Rocha, F., Dias, A. and Gomes C. (2000b). Aplicação de parâmetros mineralógicos na caracterização de sedimentos superficiais da plataforma continental adjacente ao Estuário do Guadiana. Actas do $3^{\circ}$ Simpósio sobre a Margem Ibérica Atlântica, Univ. Algarve, pp. 409-410.

Machado, A., Rocha, F., Dias, A. and Gomes, C. (2001a). Application of statistical analysis to clay minerals data corresponding to recent sediments from the continental shelf adjacent off Guadiana estuary. Nuevas Tendencias en el Estudio de las Arcillas (Actas XVI Reun. Cient. Soc. Esp. Arcillas), pp. 92-94.

Machado, A., Rocha, F., Dias, J.A. and Gomes, C. (2001b). Mineralogical characterisation of fine sediments of the continental shelf off Guadiana estuary. Actas do V Congresso do Quaternário de Países de Línguas Ibéricas, V Reunião do Quaternário Ibérico, Lisboa, pp. 214-217.

Machado, A., Rocha, F., Gomes, C. and Dias, J.A. (2002). Clay minerals identified in the suspended particulate matter of the Guadiana estuary, during a tidal cycle. La Investigación de Arcillas en Geología, Agricultura, Medio Ambiente y Ciencia de Materiales (Actas XVII Reun. Cient. Soc. Esp. Arcillas), pp. 177-180.

Martin, J.M. and Meybeck, M. (1979). Elemental mass-balance of material carried by major world rivers. Mar. Chem., 7:173-206.

Martins, V., Gomes, C., Dias, J., Rocha, F., Sequeira, C., Gomes, V., Moreno, J. and Mendes, I. (2001a). Palaeoceanographic reconstruction of the Galician continental slope during the Quaternary based on sediment textural features and on foraminifera density and characteristics. Actas do V Congresso do Quaternário de Países de Línguas Ibéricas, V Reunião do Quaternário Ibérico, Lisboa, pp. 218-222.

Martins, V., Rocha, F., Sequeira, C., Jouanneau, J., Weber, O., Gomes, C., Dias, J.A. and Gomes, V. (2001b). Clay mineral assemblages, sediment texture and foraminifera biostratigraphy used for palaeoceanographic reconstruction of the Galicia continental shelf during the Holocene. Nuevas Tendencias en el Estudio de las Arcillas (Actas XVI Reun. Cient. Soc. Esp. Arcillas), pp. 98-101.

Martins, V., Rocha, F., Gomes, V. and Gomes, C. (2002). Clay minerals and foraminifera assemblages used to identify climatic and sea level changes registered in the Holocenic sedimentary record of Ria de Vigo. La Investigación de Arcillas en Geología, Agricultura, Medio Ambiente y Ciencia de Materiales (Actas XVII Reun. Cient. Soc. Esp. Arcillas), pp. 101-105.
Mason, B. and Moore, C.B. (1982). Principles of Geochemistry. 4th ed. Wiley, New York.

Nelson, C.H. and Lamothe, P.J. (1993). Heavy metal anomalies in the Tinto and Odiel river and estuary system, Spain. Estuaries, 16: 496-511.

Oliveira, A., Rocha, F., Alveirinho Dias, J., Gomes, C. and Rodrigues, A. (1998). Bottom sediments of the northern Portuguese shelf: Patterns of clay minerals distribution. Proc. 2nd Mediterranean Clay Meeting, Univ. Aveiro, 2, pp. 173-179.

Oliveira, A., Vidinha, J., Rocha, F., Rodrigues, A., Jouanneau, J., Dias, J.A. and Gomes, C. (2000). Discriminant analysis applied to the mineralogy of sediments (fine and clay fractions) from the NW Iberian margin. Proc. 1st Latin American Clay Conference, Ass. Port. Argilas, 2, pp. 7-13.

Oliveira, A., Rocha, F., Rodrigues, A. and Dias, J.A. (2001). Mineralogy of the fine fraction of the sediments as dynamic sedimentary tracers: NW Iberian margin. Thalassas, 17: 35-44.

Oliveira, A., Rocha, F., Rodrigues, A., Jouanneau, J., Dias, J.A., Weber, O. and Gomes, C. (2002). Clay minerals of the sedimentary cover from the Northwestern Iberian shelf. Prog. Oceanogr., 52(2-4): 233-247.

Pérez, M., Usero, J., Gracia, I. and Cabrera, F. (1991). Trace metals in sediments from the "Ria de Huelva". Toxicol. Environ. Chem., 31-32: 275-283.

Ruiz, F. (2001). Trace metals in estuarine sediments from the southwestern Spanish coast. Mar. Pollut. Bull., 42(6): 482-490.

Taylor, S.R. and McLennan, S.M. (1988). The significance of the rare earths. In: K.A. Gschneider Jr. and L. Eyring (eds.), Geochemistry and Cosmochemistry. Handbook on the Physics and Chemistry of Rare Earths. Elsevier Science Publ. B.V., 11, pp. 485-578.

Turekian and Wedepohl (1961). Distribution of the elements in some major units of the Earth's crust. Geol. Soc. Am. Bull., 72: 175-192.

Vidinha, J., Rocha, F., Andrade, C. and Gomes, C. (1998). Mineralogical characterization of the fine fraction of the beach and dune sediments situated between Espinho and Torreira (Portugal): A geostatistical approach. Cuaternario Geomorfol., 12(3/4): 49-56.

Vidinha, J., Oliveira, A., Rocha, F. and Gomes, C. (2000). Clay minerals distribution in the littoral and continental platform in relation to circulation/paleocirculation. Proc. International Symposium on Clays in Relation to Environment and Industry, ISCREI 2000, Annamalai University (India), pp. 45-58.

Vidinha, J., Rocha, F. and Andrade, C. (2002). Source areas of recent sediments of the Portuguese western Atlantic coast (Espinho Cape Mondego). Mineralogical Evidences. Proc. Littoral'2002, 6th EUROCOAST International Conference, II, pp. 477-483. 